\title{
PROLOGUE
}

\section{Napoleon the Prisoner}

\begin{abstract}
$\Lambda$ T FIRST LIGHT on 15 July 1815 Captain Frederick Lewis Maitland of HMS Bellerophon stood on the quarterdeck and gazed intently towards the distant town of Rochefort. For over a month, Maitland and his crew had blockaded the French port with considerable success. A number of coasting craft had bravely attempted to leave the port, but each had been swiftly captured: some of the seized vessels were sent to Britain to be sold, while others were cast adrift and used as targets for gunnery practice. Maitland's command off the west coast of France was, in many ways, entirely typical of countless naval operations conducted by the Royal Navy during the Napoleonic Wars. Throughout the conflict, British warships were stationed around Europe, carefully positioned to reconnoitre and attack enemy vessels and harass the commerce of the French Empire. This particular morning, however, Captain Maitland was confronted with a very different undertaking. As he looked out over the water a vessel flying a flag of truce slowly approached. The ship was L'Epervier, a small, nondescript brig-of-war that on any other day would have prompted Bellerophon to prepare its fore guns in expectation of an easy capture. But today the guns stayed silent. As Maitland and the crew of Bellerophon knew, the approaching vessel contained a unique cargo: on board was Napoleon Bonaparte, until recently the Emperor of France and commander of its armies. After twelve years of conflict, he was about to surrender. ${ }^{1}$

One month earlier, Napoleon had fought and lost the Battle of Waterloo, bringing his illustrious career to an abrupt end. With his army crushed, his political support failing and the allied forces of Britain and Prussia circling behind him, Napoleon abdicated and retreated westwards. First he went to Paris, and then to Rochefort, where he hoped to find a ship to take him to America. Instead Napoleon found Maitland's Bellerophon waiting, blocking his escape. Not for the first time, his plans were thwarted by the Royal Navy.
\end{abstract}


'Wherever wood can swim, there I am sure to find this flag of England,' a despondent Napoleon commented. ${ }^{2} \mathrm{He}$ and his aides discussed his options; none was particularly appealing. Napoleon could expect little generosity from the advancing armies, and he may have heard rumours that the Prussians had received orders not to take him alive. With the escape routes blocked, his aides entered into complex negotiations with Maitland, attempting to secure certain guarantees. However, no amount of diplomacy could hide the weakness of Napoleon's position. Maitland was adamant that he did not have the authority to grant a passport to America, and without this guarantee Napoleon was racked with indecision. On 14 July, desperately short of options, he finally agreed to throw himself on the mercy of Britain.

On Bellerophon, the news of Napoleon's decision sparked the crew into action, and preparations for the former emperor's arrival continued throughout the night. Maitland himself caught only a few hours' sleep, and by 5.30 a.m. on 15 July he stood apprehensively watching L'Epervier approach. The next few hours promised to be the defining moment in the war, for with Napoleon came the prospect of peace and the end to a conflict that had engulfed Europe for over a decade. For Maitland, a man whose naval career had been conventional rather than extraordinary, it offered the possibility of significant prestige. No naval officer could hope to capture a greater prize, and as the tension built Maitland began to pace back and forth between the gangway and his cabin, casting impatient glances at the French brig as it drew nearer. Among his crew, anticipation also grew, as Napoleon's arrival on Bellerophon promised to bring them face to face with the man who had dominated European affairs for as long as they could remember. 'This is the proudest day of your life,' a midshipman told the ship's boatswain, James Manning, for he was about to meet the 'greatest man the world has ever produced or ever will produce'. ${ }^{3}$

To the waiting crew on Bellerophon, Napoleon was an object of considerable fascination. As a general, First Consul and then Emperor of France, he had committed Europe to a conflict more damaging than any previous war, bringing immense devastation to the Continent as once powerful nations were overrun by his victorious troops. Indeed, the Napoleonic Wars, as they would become known, remain one of the few conflicts in history to be named after an individual, a testament to the violent, indelible imprint he left on his age. His renown was particularly apparent in Britain, which had been locked in an intense conflict with France since 1803. Napoleon had become the bogeyman of British popular culture, represented in prints, caricatures and newspapers as the devil incarnate, a 'Corsican Ogre' capable of beastly acts and dominated by an unceasing lust for power. But, as the remarks of Bellerophon's star-struck midshipman testified, there was also 
great admiration for a man who had risen from obscure origins to oversee an empire that at one point stretched from Spain to the Russian border. ${ }^{4}$

Napoleon's arrival on board, then, was a once-in-a-lifetime opportunity for the men serving in Bellerophon. Much to their frustration, however, the French brig struggled in the face of a headwind, and to some spectators it appeared almost stationary. Unable to observe the vessel's glacial progress any longer, Maitland's patience snapped, and he ordered his first lieutenant, Andrew Mott, to take the ship's barge and intercept the brig. The oared vessel cast off towards L'Epervier, and the waiting crowd watched as a small group of uniformed individuals clambered aboard before the barge turned and headed back. To Maitland's great relief, and to the obvious excitement of the crew, at 6 a.m. Napoleon Bonaparte climbed on board Bellerophon. The ship's marines snapped to attention and Napoleon took off his hat, and stating simply in French, 'I am come to throw myself on the protection of your Prince and your laws. ${ }^{5} \mathrm{He}$ was taken to the great cabin, where he asked to be introduced to the ship's officers; they quickly learned that the prisoner's instinctive charm had not deserted him. Napoleon interviewed each of them, enquiring about their names, ranks and experience in battle, and finished with a typically complimentary flourish: 'Well gentlemen,' he said, 'you have the honour of belonging to the bravest and most fortunate nation in the world.' He was then led on deck and took a tour, seeing for the first time the anatomy of a British ship of the line. ${ }^{6}$ It would be his home for the next few weeks as he was transported back to Britain, a prisoner of the Royal Navy.

In stepping on board Bellerophon, Napoleon's capitulation assumed a powerful significance. Commentators were quick to pick up on the symbolic irony, contrasting his captivity on board a naval ship with his long-held maritime ambitions. As the Leeds Mercury recorded:

'How the Mighty have fallen!' Napoleon, Emperor of France, that potentate on whose behest the fate of Continental Europe at no distant period depended - the founder of the Continental System - the champion of the liberty of the Seas - has surrendered unconditionally to the British navy, and cast himself upon the hospitality of the most powerful, the most constant, and the most generous of his enemies. ${ }^{7}$

Indeed, Napoleon found himself on board a ship that had seen almost ceaseless service during the war. Bellerophon had blockaded Cadiz, fought at the Battle of Trafalgar, and subsequently been stationed in the Channel, the North Sea and the Baltic, protecting British trade and attacking that of France and its allies. As it set sail for Britain, Napoleon watched captivated 
as the ship's crew executed tasks that were second nature after twelve years of war. He was amazed by the professionalism of the British sailors, and wondered at the relative silence in which they carried out their orders. Ever inquisitive, he examined the sights on the guns, remarking favourably on the speed and skill of British gunnery. Napoleon noted that French ships were generally larger, and carried more guns and men, but now he knew why they tended to lose to their British opponents. The British seamen, he stated, 'were surely a different class of people from the French'. ${ }^{8}$

For the next three months Napoleon was imprisoned on naval vessels as he was carried into exile. Taken first to Torbay, then to Plymouth, he was finally transferred to the 74-gun Northumberland for the ten-week voyage to St Helena, where he lived out the rest of his life. The long journey to this distant and desolate island afforded further opportunity for Napoleon to witness the proficiency of the Royal Navy, but also to analyse its role in his defeat. Each day he dined with his captors, who bombarded him with questions about the war. His answers alternated between jovial bonhomie and sadder, more introspective responses, in which his disappointment and even anger at recent failures were manifest. He talked of the disastrous Russian campaign that destroyed his Grande Armée in 1812, and his final defeat at Waterloo. He criticised his generals, and contemplated a number of missed opportunities that had cost him dearly. More often than not, though, the conversation turned to the war at sea. In particular, he talked about his numerous attempts to invade Britain, which had foundered as a result of his inability to outwit the Royal Navy. Unsubtly, he attempted to shift the blame for his defeat on to his naval subordinates, and bewailed the 'want of maritime knowledge' in France. He spoke repeatedly of the failures of his admirals, and argued that they were 'quite unaccustomed to command in any difficult or trying circumstances'. When his fleet commanders did come into contact with the British they 'lost their heads', became 'quite confused', and did 'precisely what they ought not'. An invasion of Britain was deemed impossible, he said, 'from the moment he found his fleets had failed him'. Had troops been successfully landed, he had no doubt that they would have quickly conquered the country. ${ }^{9}$

Napoleon's comments were undoubtedly harsh, but reflected a very real appreciation of how the war at sea had proved his undoing. Surrounded by naval officers, Napoleon was determined to show his companions not only that he understood the importance of maritime warfare, but that he had devoted considerable time and effort to improving France's naval fortunes. He spoke dreamily of his ambitions to turn the French navy into a force that could overturn the Royal Navy's superiority and compel Britain to accept the 'Independence of the Seas'. He had turned the captured city of 
Antwerp into a productive dockyard and spent the vast sum of $£ 3$ million improving the basin at Cherbourg to make it into 'a naval port of the first rank'. He had commissioned surveys into French shipbuilding timber and discovered there was sufficient quantity for constructing a thousand ships of the line, while a new system of marine conscription was designed to provide 'as many seamen as he pleased'. ${ }^{10}$ For all of Napoleon's characteristic bombast, these plans were far from illusory; they were examples of a very real programme of naval investment conducted over the previous decade. Right until the end of the war, Napoleon continued to challenge British naval mastery, but time and time again his efforts were scuppered by the Royal Navy.

To Napoleon, and to the captivated naval officers who enjoyed his company over dinner, it was self-evident that the Royal Navy had played a crucial role in deciding the outcome of the war. However, two hundred years on from these momentous events, the navy's role in the Napoleonic Wars and the conflict at sea in general has been overlooked, if not entirely forgotten. Although Napoleon surrendered to the Royal Navy, it is the terrestrial war that has attracted the lion's share of scholarly and popular attention. In 2015, the bicentenary of the end of the Napoleonic Wars concentrated almost solely on the Battle of Waterloo, marking it with a wide array of commemorative events and a vast outpouring of publications that covered the battle and its legacy. Such is the power of the anniversary to focus contemporary attention on a key event from the past, and it is understandable that politicians, historians and the public alike have highlighted Napoleon's final battlefield defeat as a moment worthy of special recognition. However, this focus on a single event is problematic as it neglects one of the most important and most fascinating dimensions of the war; namely, that fought on the world's oceans. This was no sideshow: indeed, the conflict at sea was a vital theatre in which Napoleon's ambitions were persistently and irretrievably crushed.

This book tells the story of the naval war fought against Napoleon from 1803 until 1815, when the Royal Navy offered constant opposition to the French emperor as he strove to achieve complete dominance of Europe. In the early years of the war, the Royal Navy thwarted all of his attempts to invade and conquer Britain, until he was finally persuaded that such an undertaking was impossible. It fought a series of great battles that allowed Britain to control the world's oceans - repeatedly upsetting Napoleon's attempts to transform France into a naval power - and conducted raids that eroded its shipbuilding efforts. It blockaded much of the European continent, preventing the remaining French fleets from leaving port, and ensuring that neutral fleets were kept from Napoleon's grasp. It oversaw 
amphibious expeditions and provided crucial logistical support to armies across Europe. Naval forces around the globe captured numerous enemy colonies, extending the British Empire, boosting trading revenues, and providing vast sums that allowed Britain to subsidise allies in Europe. Lastly, and perhaps most crucially, British naval power weakened Napoleon's great economic project, the Continental System, in the process undermining his imperial authority and the French economy, and forcing many of France's allies to turn against Napoleonic rule. It is not too much to say that the entirety of the British war effort rested upon the Royal Navy.

Napoleon's decision to surrender to the navy in 1815 was therefore a deeply symbolic moment, for when he stepped on board HMS Bellerophon the former French emperor yielded to the force that had offered the most constant and effective opposition to his mastery of Europe. In 1803, he had entered the war with Britain confident that his dominance on land could be easily replicated at sea, and throughout the war his maritime ambitions tested the Royal Navy to its limits. By 1815, however, he was a defeated man, forced to sail into captivity within the wooden walls of a British warship. After his long voyage, Napoleon arrived on the rocky island of St Helena, where he confided to his surgeon that the Royal Navy was 'the real force and bulwark of England'. ${ }^{11}$ The long years of war had given him ample reason to believe this was the case, for the navy represented not only his most implacable enemy, but also the force that had played a vital role in ensuring his final defeat. 


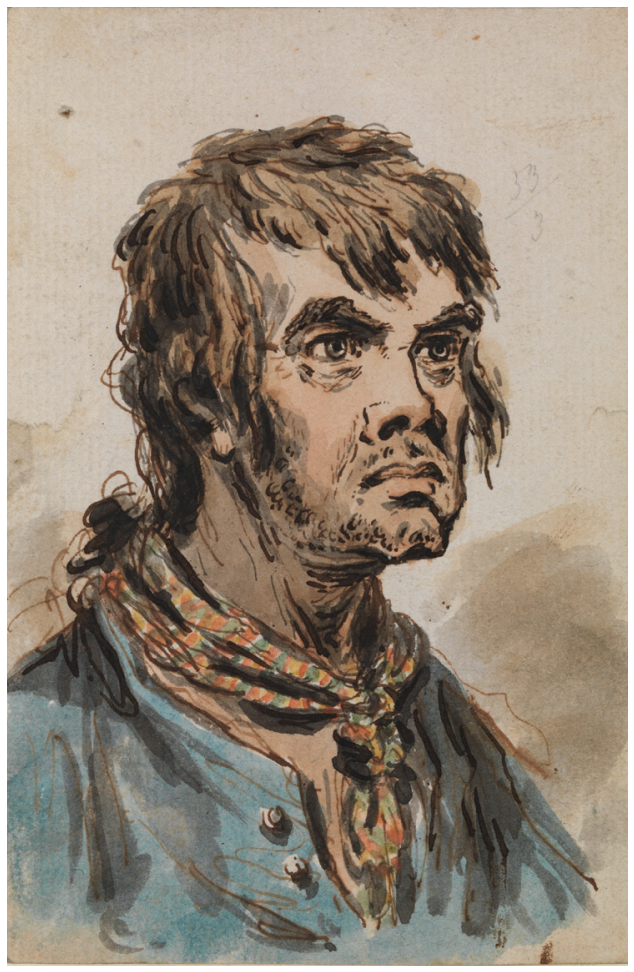

1 An incredibly rare image of a sailor, attributed to the famous caricaturist James Gillray.

Though his features are no doubt exaggerated, the individual's unkempt hair and prominent neckerchief set him apart as a seaman. Very few people encountered sailors in their daily lives, but they nonetheless occupied a prominent place in British popular culture.

2 The vast majority of naval seamen were volunteers. Many of them responded to recruitment posters like this, with its blatant mixture of patriotic bluster and financial inducement. The 'Royal Tars' referred to here would have joined the navy for a variety of reasons, from steady pay and the prospect of prize money, to the promise of adventure and a regular meal.

\section{VOLUNTEERS.}

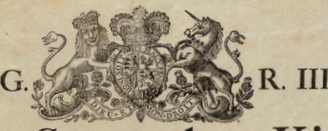

\section{God Save the King.}

LT us, who are Englifhmen, protect and defend our good KING and COUNTRY againt the Attempts of all Reppublicans ard Levellers, and againt the Defigns of our NATURAL

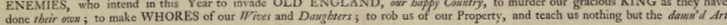

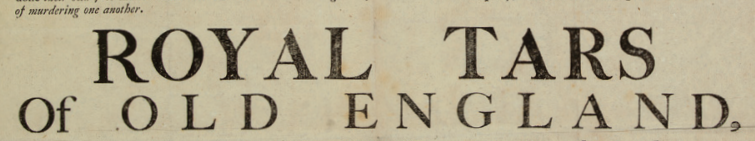

If you love your COUNTRY, and your LIBERTY, now is the Time to fhew your Love.

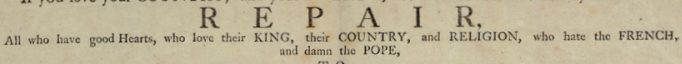

\section{Lieut. W. J. Stephens,}

\section{At his Rendezvous, SHOREHAM,}

Where they will be allowed to Enter for any SHIP of WAR, BOUNTIES will be given by his MAJESTY, in Addition to Two Months Advance.

To Able Seamen, - $\quad$ - $\quad$ - Five Pounds.

To Ordinary Seamen, _ _ _ _ T Too Pounds Ten Shillings.

To Landmen, - _ _ _ Thirty Sbillings.

Condut-Money paid to go by Land, and their Chefts and Eedding fent Carriage free.
Thofe Men who have ferved as PETIY-OFFICERS, and thofe whe are ortherwife qualified, will be recommended accordingly LEWES, PRINTED BY W. AND A. LEE. 


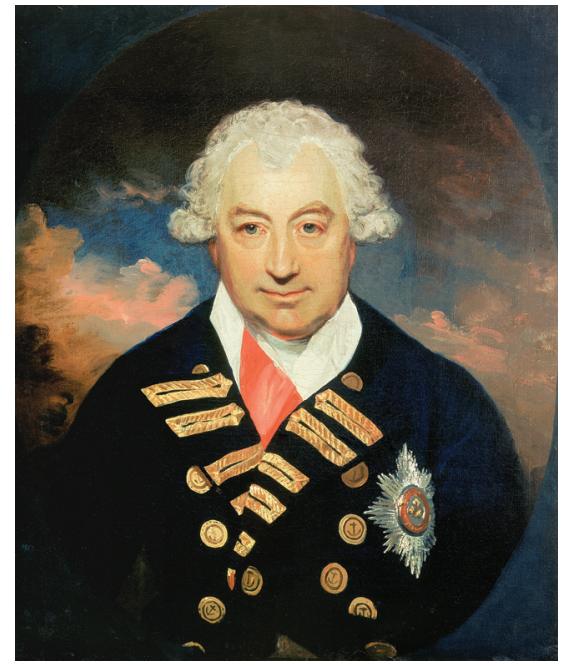

3 This portrait shows John Jervis, Lord St Vincent, gazing with characteristic intensity at the viewer. Obstinate to the point of pigheadedness, his controversial term as First Lord of the Admiralty was marked by widespread rancour, and he left the Royal Dockyards in utter disarray. In 1806 he returned to active naval command, much to the displeasure of his fellow officers in the Channel Fleet.

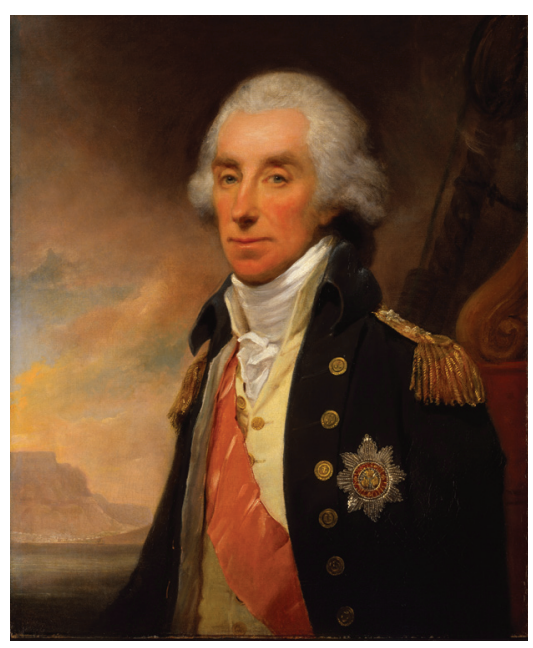

5 Irritable and often cantankerous, George Keith Elphinstone, 1st Viscount Keith, proved a persistent thorn in Napoleon's side throughout the war. Initially given command of the North Sea Fleet, his ceaseless blockade of the French invasion force at Boulogne ensured that it never succeeded in leaving port. Keith later commanded the Channel Fleet, and was on hand at Plymouth to receive Napoleon when he arrived as a prisoner in 1815 .

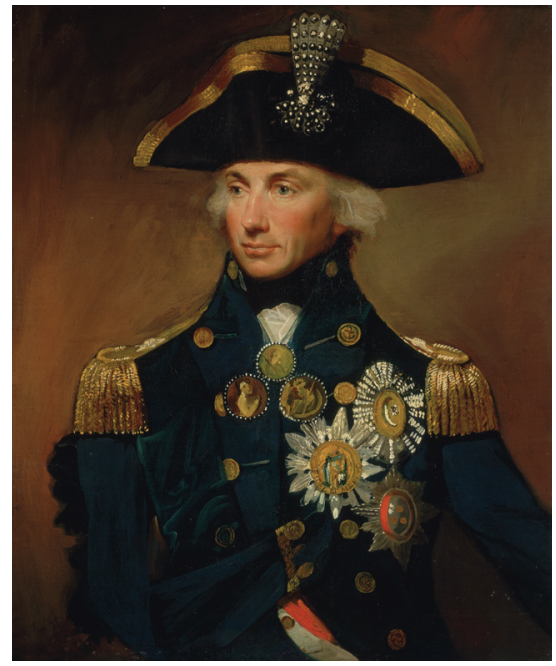

4 As victor of the Battle of the Nile and Copenhagen, Horatio Nelson was the most celebrated naval officer of his generation. Given the command of the Mediterranean Fleet, he spent the first two years of the conflict fighting an exhausting cat-and-mouse campaign that tested his stamina and skill to the utmost. His victory at the Battle of Trafalgar cemented his place in national folklore.

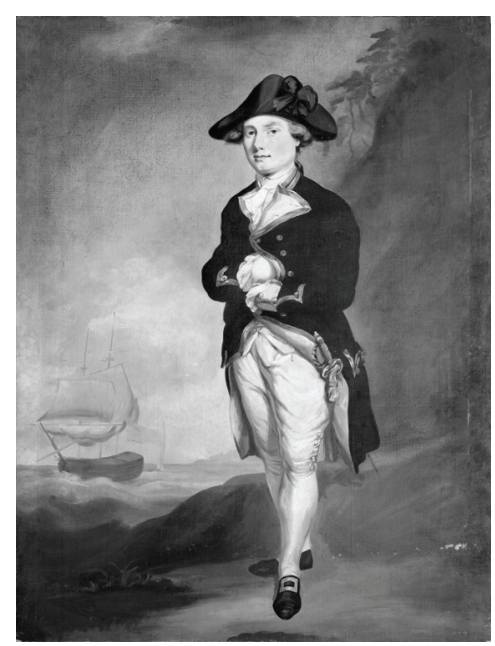

6 At the outset of the war William Cornwallis was given command of the Channel Fleet, perhaps the most important naval station. He was unrefined in comparison to some of his peers, but he proved a steadfast and popular leader; he was deeply respected by his sailors, who nicknamed him 'Billy Blue'. Though he never commanded a fleet in a decisive battle, he retired in 1806 having embodied the professionalism of the Royal Navy's officer corps. 


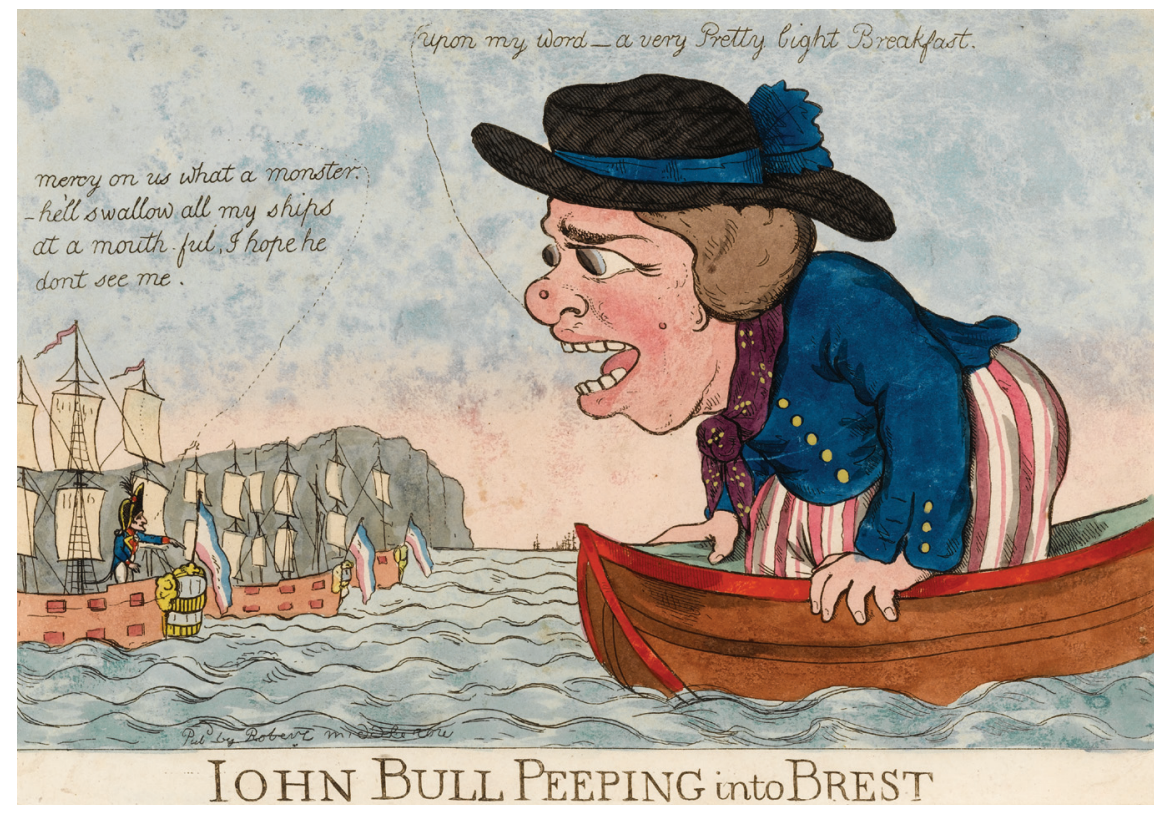

7 Published in 1803 soon after the outbreak of war, the print JOHN BULL PEEPING into $B R E S T$ shows the symbolic representation of the British people dressed as a naval seaman gazing down on the French fleet confined in port. As he hungrily appraises them as 'a very Pretty light Breakfast', a diminutive Napoleon shrieks in terror at the oversized monster threatening his ships. In reality, the Channel Fleet was content to contain the French forces in early months of the war, but this print shows that public faith in the navy remained high.

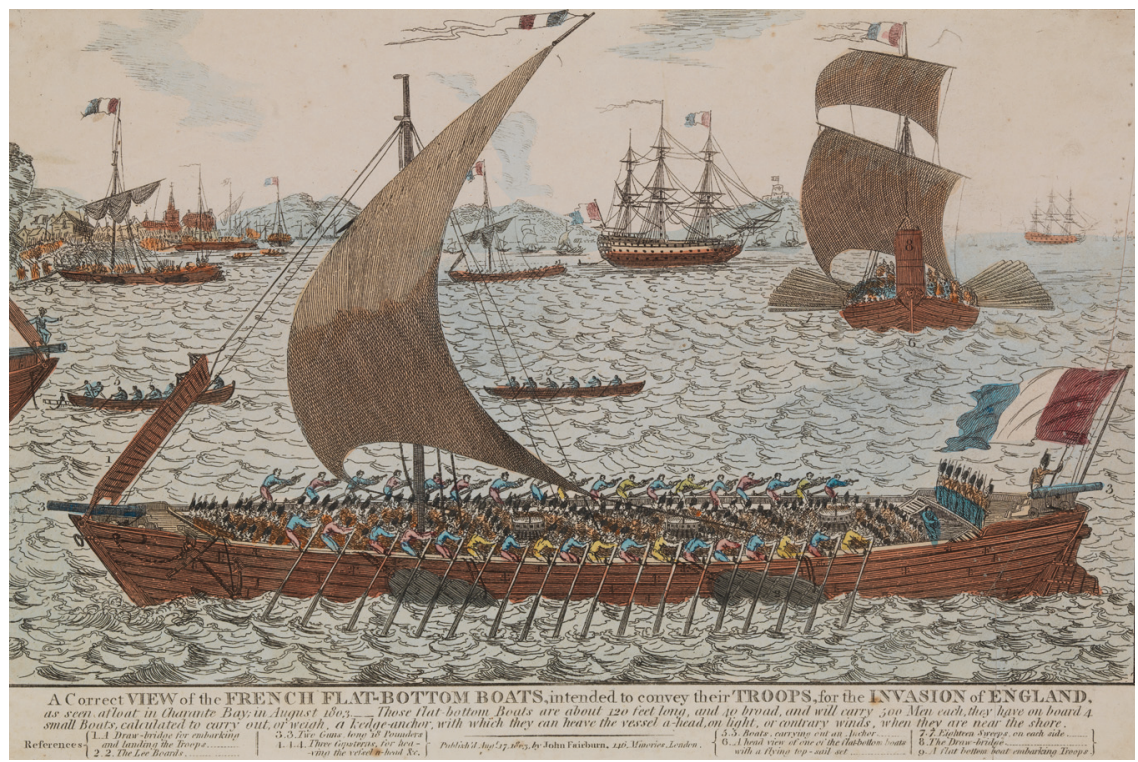

8 A few months into the war, rumours of a burgeoning French invasion flotilla across the Channel provoked considerable fear in Britain. Prints depicting vast invasion craft each capable of carrying up to 500 troops fuelled national anxieties and even the most absurd images were based on the very real prospect of a French force landing on British shores. While militias were mobilised and national defences improved, the security of the nation rested firmly on the shoulders of the Royal Navy. 


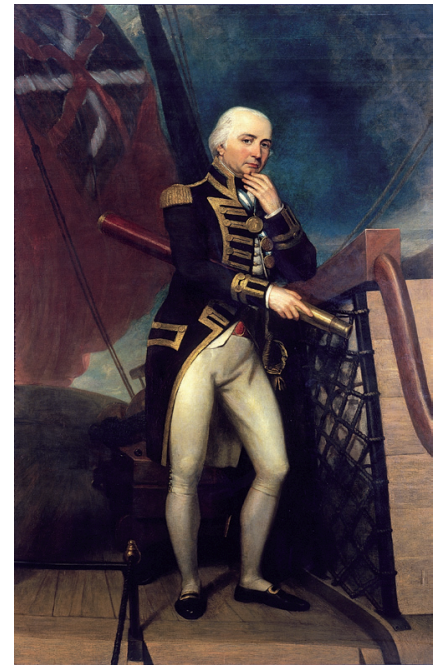

9 Cuthbert Collingwood played a vital role in the Battle of Trafalgar, and took command of the British force after the death of his close friend, Horatio Nelson. He subsequently commanded the Mediterranean Fleet and made himself indispensable, to the extent that the Admiralty refused to relieve him. Exhausted and increasingly depressed, he was forced to remain at sea until his death in 1810 .

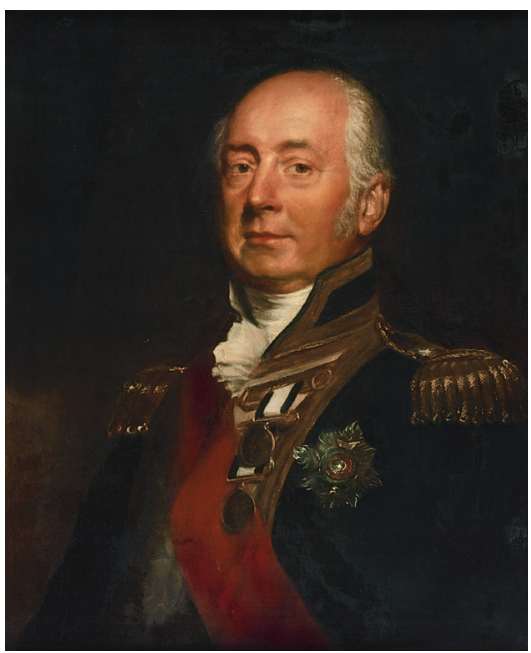

11 A Guernsey-born naval commander, James Saumarez was described by St Vincent as 'an officer whose merit cannot be surpassed'. Sincere but sometimes considered aloof, his command of the Baltic Fleet from 1808 was a masterclass in diplomacy and pragmatic politics, safeguarding British trade with the region. His achievements in this theatre were crucial to the British war effort, and he fully deserved his elevation to the peerage in 1831 .

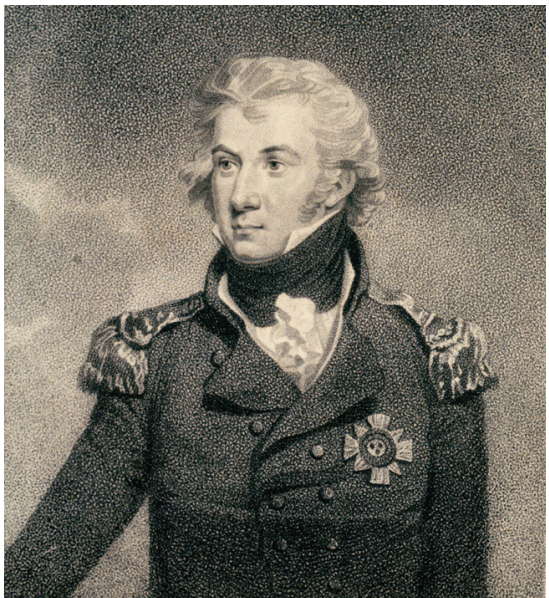

10 Without doubt one of the most charismatic officers of the era, the vainglorious and cocksure Sir Sidney Smith had an unrivalled ability to alienate fellow commanders; both Keith and Collingwood attempted to sideline him, with varying degrees of success. He did not serve after 1814, but he continued to excite negative opinion. 'Of all the men whom I ever knew who have any reputation,' remarked the Duke of Wellington after the war, 'the man who least deserves it is Sir Sidney Smith.'

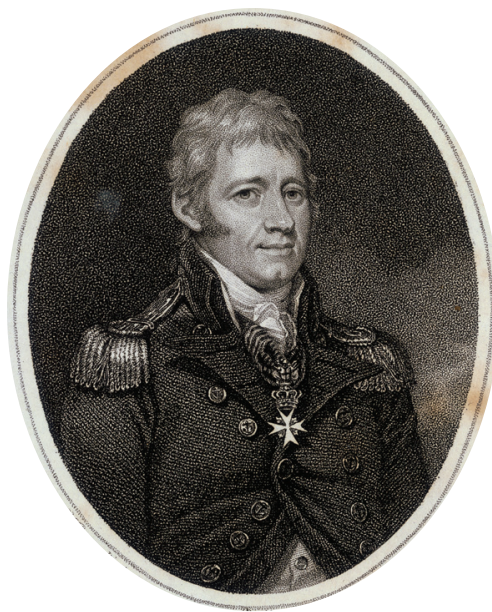

12 Unorthodox and controversial, Sir Home Riggs Popham's naval career oscillated between triumph and disaster. His capture of the Cape in 1806 was a textbook example of amphibious operations, which he unwisely followed with an unauthorised campaign to South America that ended in defeat and court-martial. Fortunate to emerge from this with his career intact, he redeemed himself in a series of actions along the north coast of Spain, for which he won fulsome praise from the Duke of Wellington. 


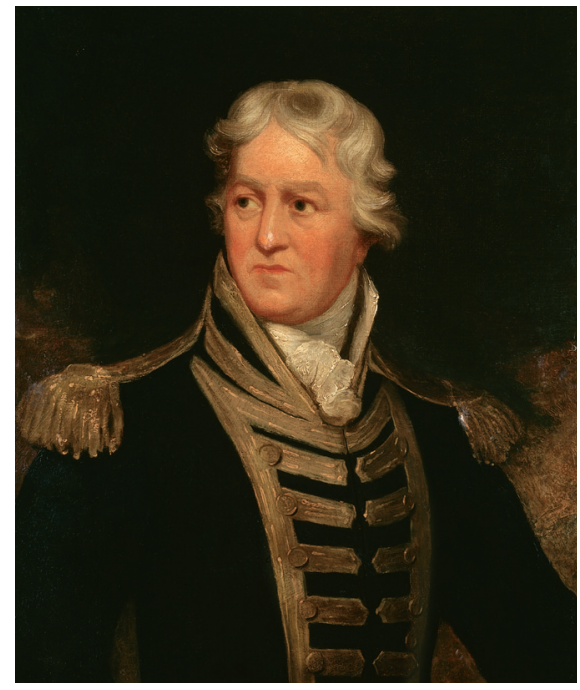

13 A man of great experience, Charles Middleton (from 1805 Lord Barham) was a calm and authoritative presence as First Lord of the Admiralty. Though his term of office was short, he steered the navy through the Trafalgar campaign, when the dangers facing the country appeared endless. At this crucial moment in the war, Britain's fleets could not have been in safer hands.

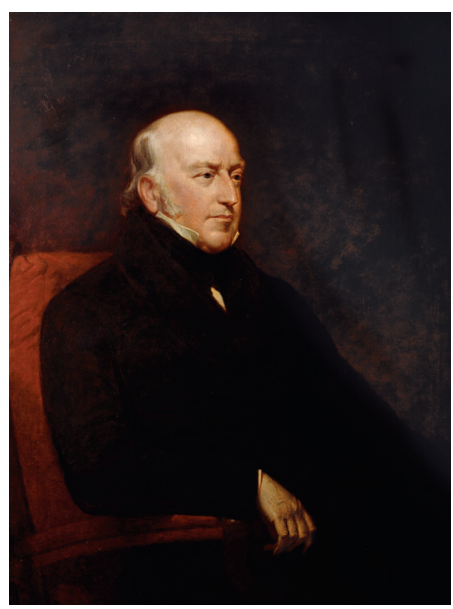

15 Edward Codrington was perhaps the ablest captain under Nelson's command at Trafalgar. During the approach he timed his attack on the enemy to perfection and was disappointed not to be mentioned in Collingwood's dispatches. He was highly critical of Edward Berry's conduct in the battle, and afterwards expressed his displeasure at Harvey's selfpromotion. Shown here in later life, he continued in active naval service until 1842, reaching the rank of Admiral.

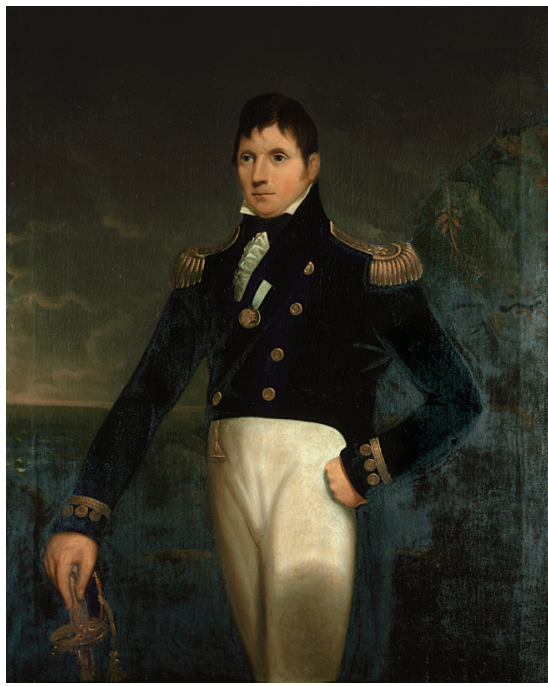

14 Eliab Harvey captained Temeraire at the Battle of Trafalgar, taking his ship into the very thick of the action. Engaged for over three hours, he forced two French ships to surrender and was the only individual picked out for commendation by Collingwood in his dispatches. Success went to his head, however, and he was later court-martialled and dismissed following a furious rant at a superior.

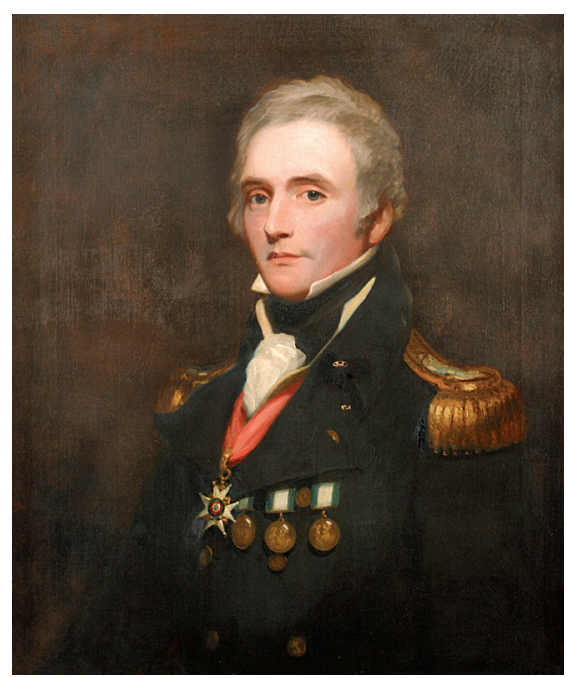

16 Captain Edward Berry represented the best and worst of the Royal Navy's officer corps. While undoubtedly brave and resolute, he could also be impetuous and hot-headed, and these conflicting sides of his character were perfectly captured by Nelson as he watched Berry's ship Agamemnon approach prior to Trafalgar. 'Here comes that damned fool Berry!' he exclaimed, 'Now we shall have a battle.' 


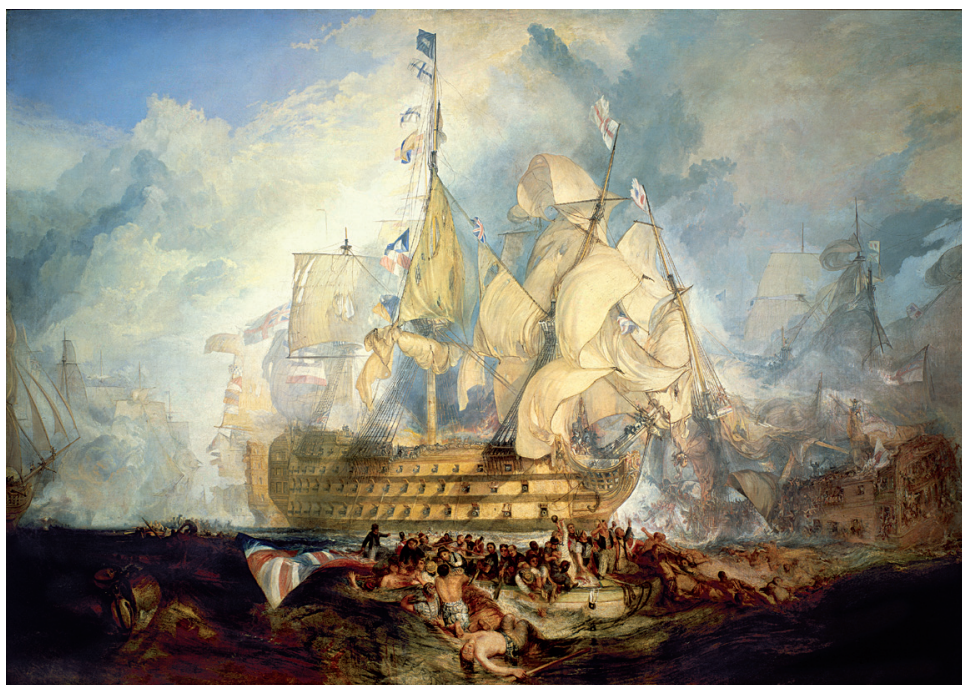

17 J. M. W. Turner's superb depiction of the Battle of Trafalgar shows Nelson's flagship Victory as a dominating expression of British sea power, with the famous signal 'England expects that every man will do his duty' prominently flying. To the right the French ship Redoubtable surrenders to the British, while in the foreground the human cost of the battle is laid bare. Although Turner was criticised for taking liberties with historical accuracy, his symbolic representation remains a defining image of British national identity.

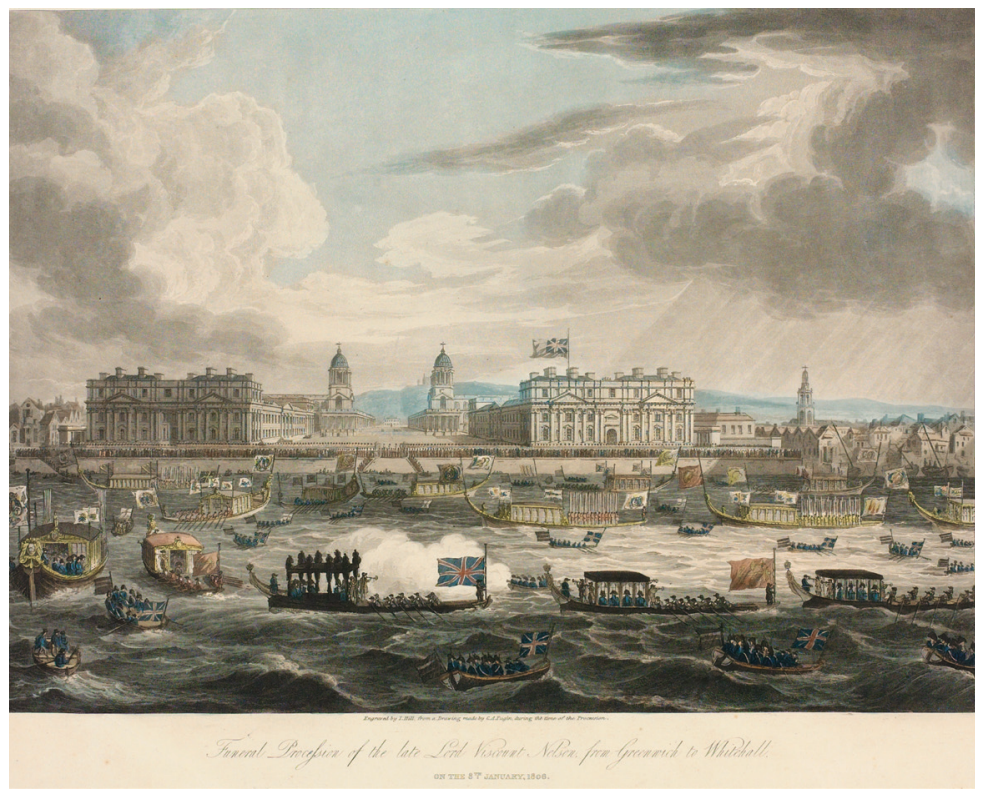

18 Nelson's funeral was a remarkable occasion attended by tens of thousands of people. For two days his body lay in state at Greenwich, before being placed in a funeral barge ready for its final voyage up the River Thames on 8 January 1806. Over sixty boats belonging to City livery companies and the Sea Fencibles accompanied the procession, and this brooding print captures some of the solemnity of the occasion. The following day Nelson's body was laid to rest at St Paul's Cathedral. 


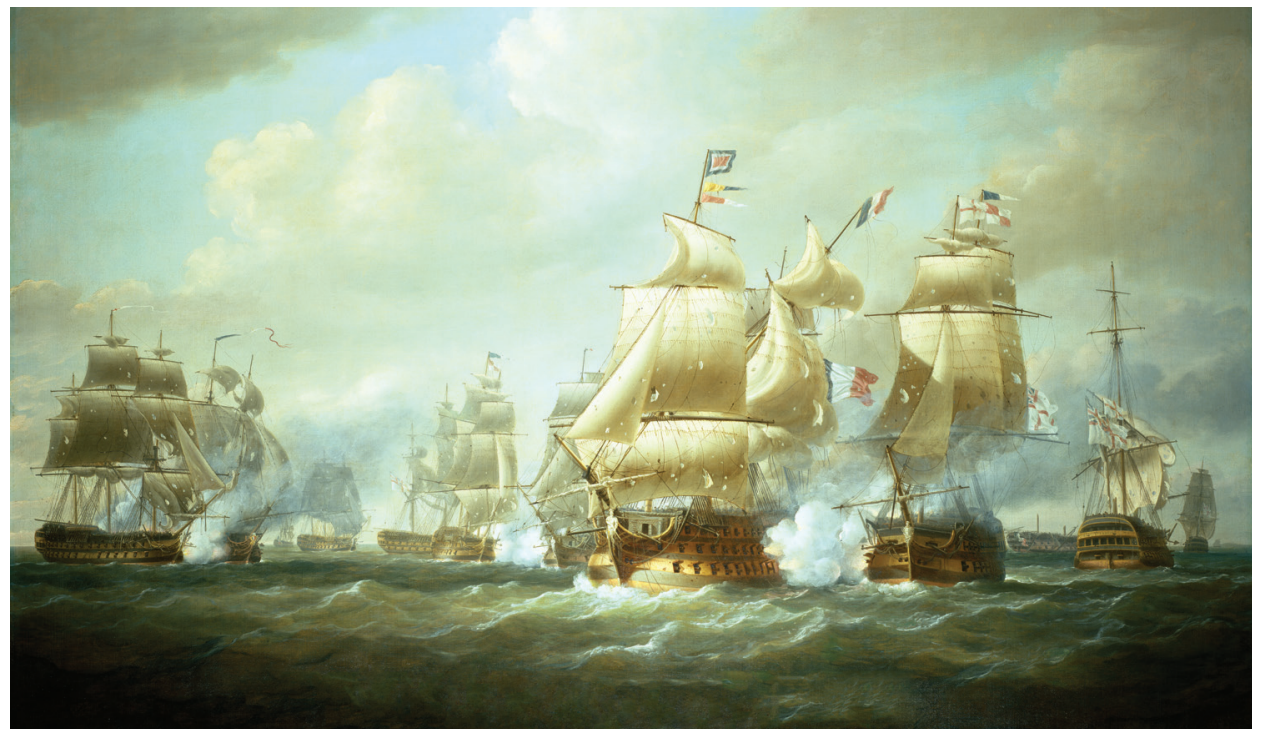

19 A few months after the Battle of Trafalgar a force under Vice-Admiral John Duckworth was involved in a major naval battle off San Domingo. Fortunate to come across Leissègues's fleet, he quickly brought it to action and inflicted a decisive blow. The 'Trafalgar of the Caribbean', as the battle has sometimes been termed, saved the British West Indies from French depredations, but was unwelcome proof that the naval war was far from over.

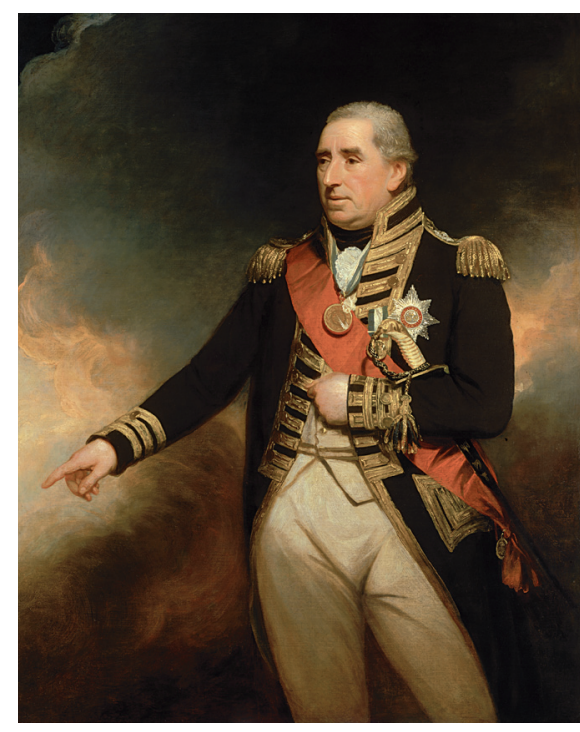

20 Despite three court-martials in his early career, John Duckworth rose to command naval fleets on a number of occasions. Victory at the Battle of San Domingo in 1806 won him considerable plaudits, but his expedition to the Dardanelles the following year resulted in an embarrassing withdrawal. Produced shortly before he was installed as Governor and Commander-inChief at Newfoundland, this portrait shows him resplendent in his medals and Order of the Bath.

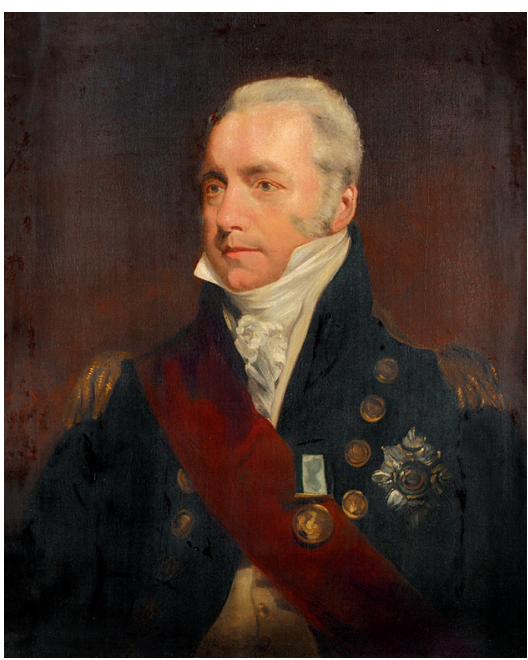

21 Although he was one of the most talented officers of his generation, a combination of ill health and bad timing ensured that Richard Goodwin Keats never commanded a major fleet. Devastated to have missed the Battle of Trafalgar due to illness, he was subsequently present at numerous actions. He served as Duckworth's flag captain at San Domingo, and later as Strachan's second in command during the Walcheren expedition. Though his career at sea ended prematurely in 1812 , he was later appointed governor of the Greenwich Hospital. 


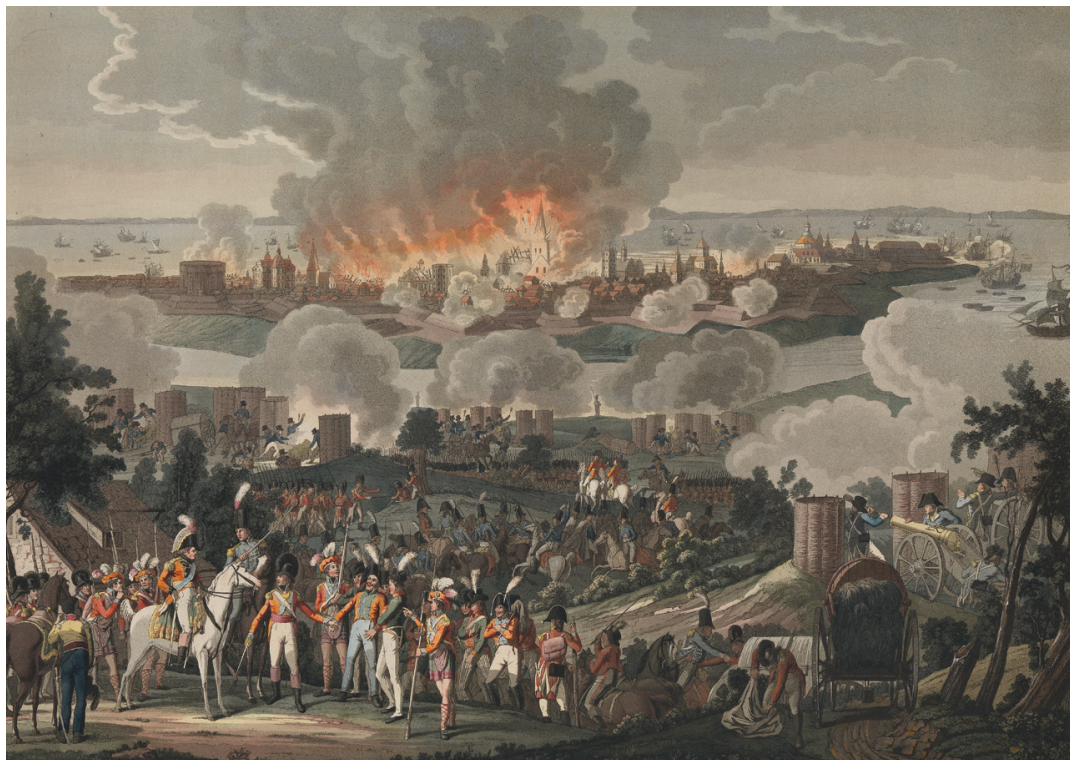

22 The attack on Copenhagen in 1807 was a brutal demonstration of British military and naval might, and a clear sign that the Cabinet was prepared to resort to any means to defeat Napoleon. While Britain succeeded in capturing the Danish fleet, hundreds of civilians were killed during the bombardment, and the operation was condemned both at home and across Europe.

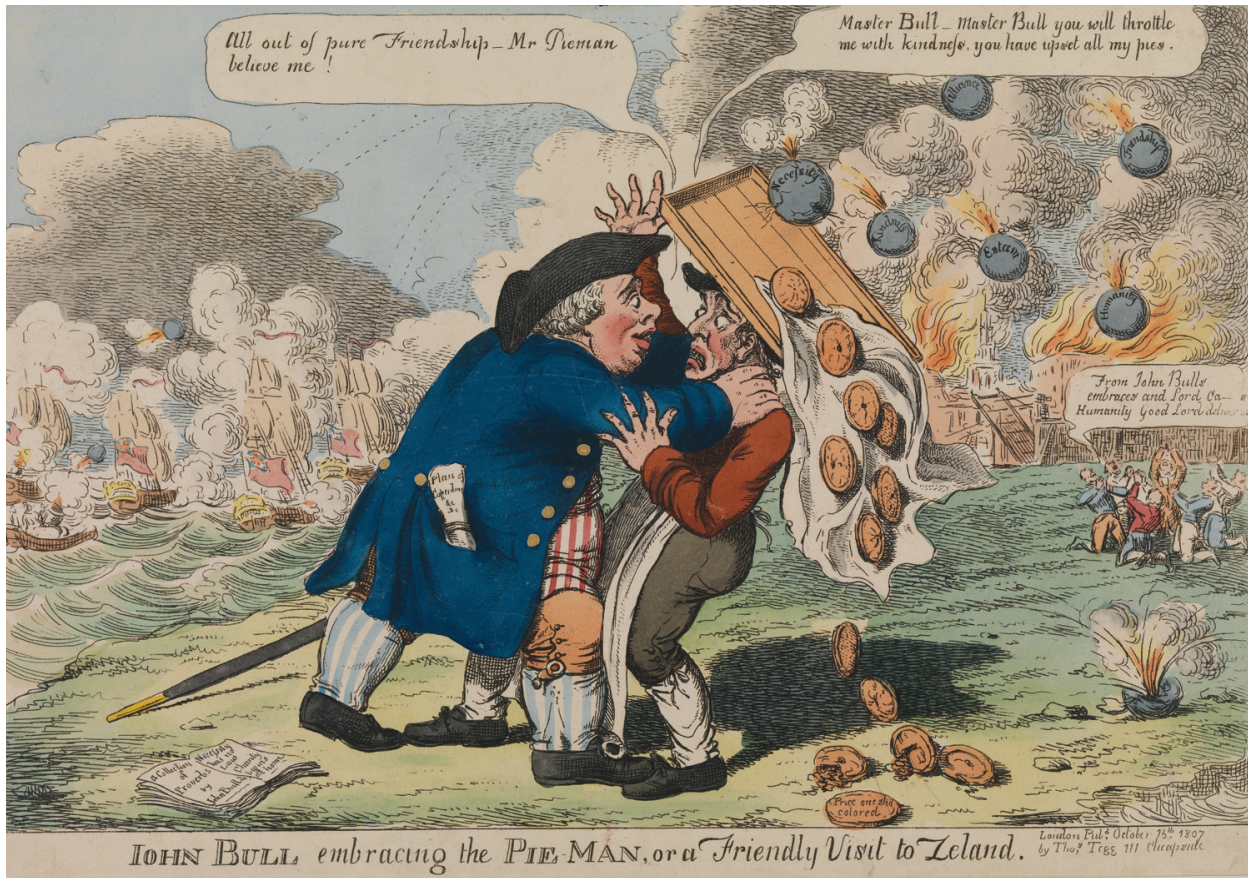

23 If some commentators defended the attack on Copenhagen as a necessary act of self-defence, others were fiercely critical. This caricature by Thomas Tegg is vitriolic in its condemnation of the operation, showing John Bull - supposedly the embodiment of British character - violently assaulting a fearful Danish baker. The pies that fall from his tray mirror the bombs falling on the city in the background. 


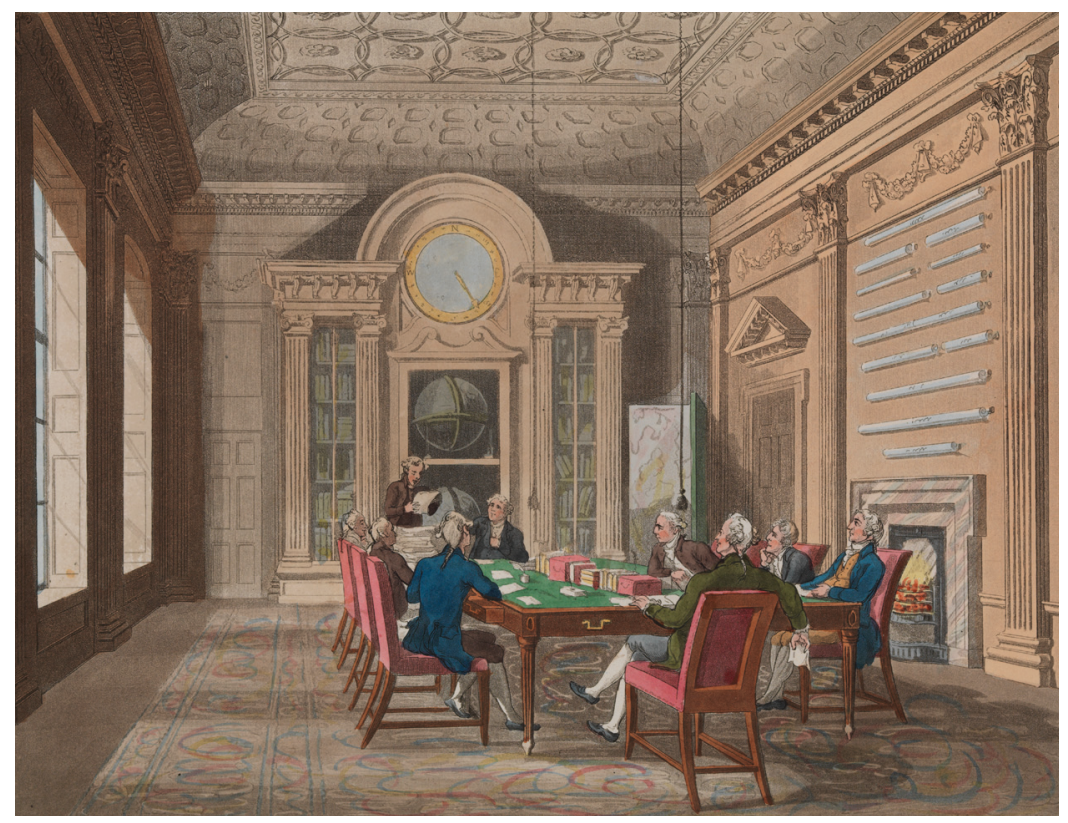

24 This print, from Ackermann's Microcosm of London (1808-11), shows the Admiralty as the nerve centre of British naval power. In this grand office on Whitehall the Lords of the Admiralty met to discuss strategy, naval deployment and intelligence, while issuing orders to commanders around the globe. The text that accompanied this image describes them engaged in business 'of more real importance to this country, than any other subject'.

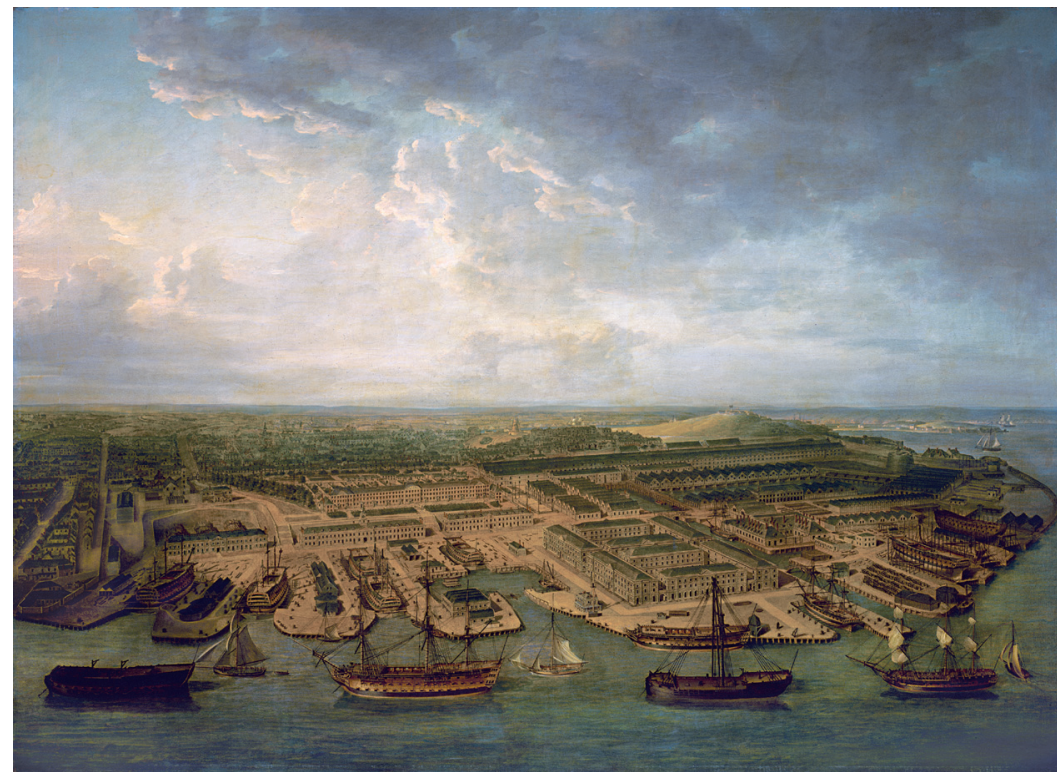

25 The navy relied on the Royal Dockyards to build, refit and sustain its ships at sea - operations that required significant state investment, as well as a large and highly skilled workforce. Plymouth Dockyard, shown here, was the most westerly of the yards, and therefore played a crucial role supporting naval fleets stationed at Brest and along the western coast of France. This painting shows the vast scale and importance of these complexes, which were the foundation of British sea power. 


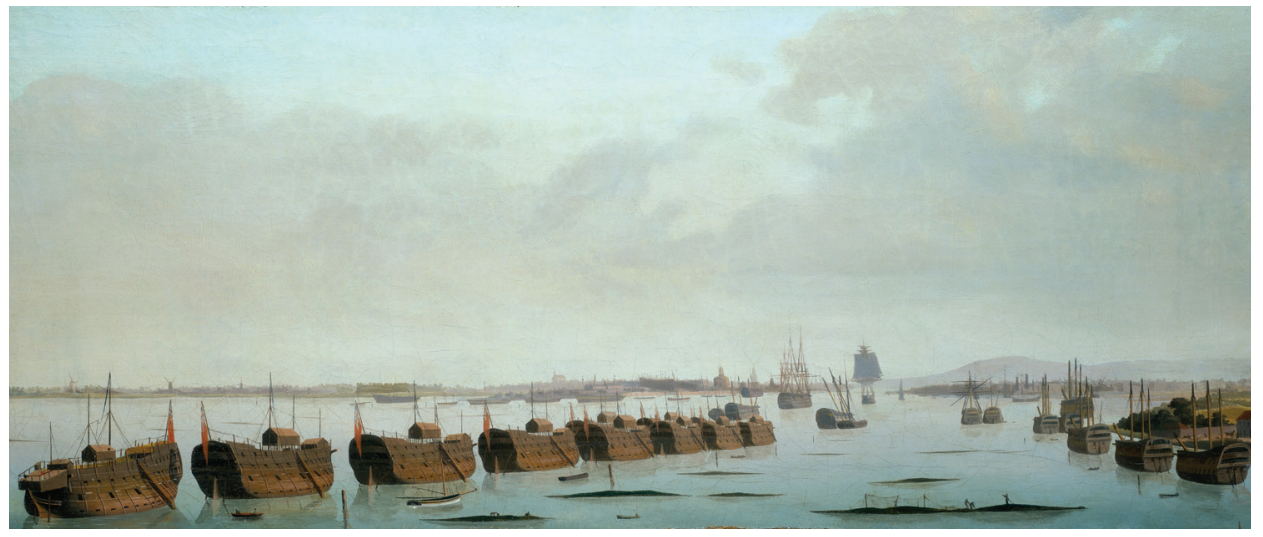

26 Many unfortunate French prisoners of war were confined in prison hulks, former naval vessels that had been converted into floating gaols. Overcrowded, with little ventilation and dalylight, conditions on board were appalling. Disease was rife and mortality rates high. Painted by Louis Garneray, a French privateering officer held as a prisoner of war in Portsmouth hulks for eight years, this image conveys the bleak nature of a prisoner's existence.

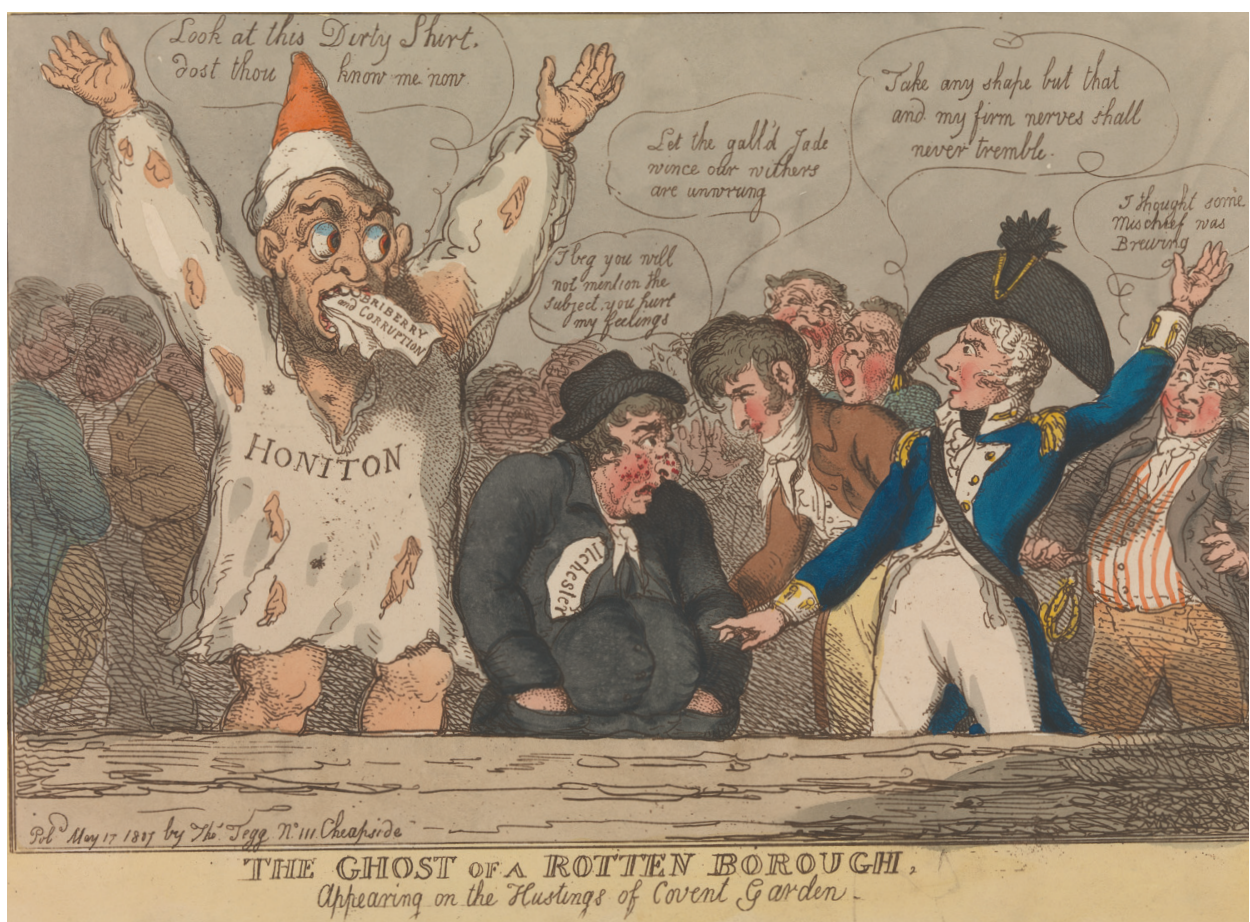

27 Thomas Cochrane was one of the most famous - and controversial - officers of the age. Alongside his naval career he was a prominent radical politician who made the most of his reputation for bravery and boldness to win over the electorate. This caricature shows him resplendent in his naval uniform attempting to win the seat of Westminster, decrying a ghost that has appeared to remind him of his earlier effort to buy the 'rotten borough' of Honiton. 


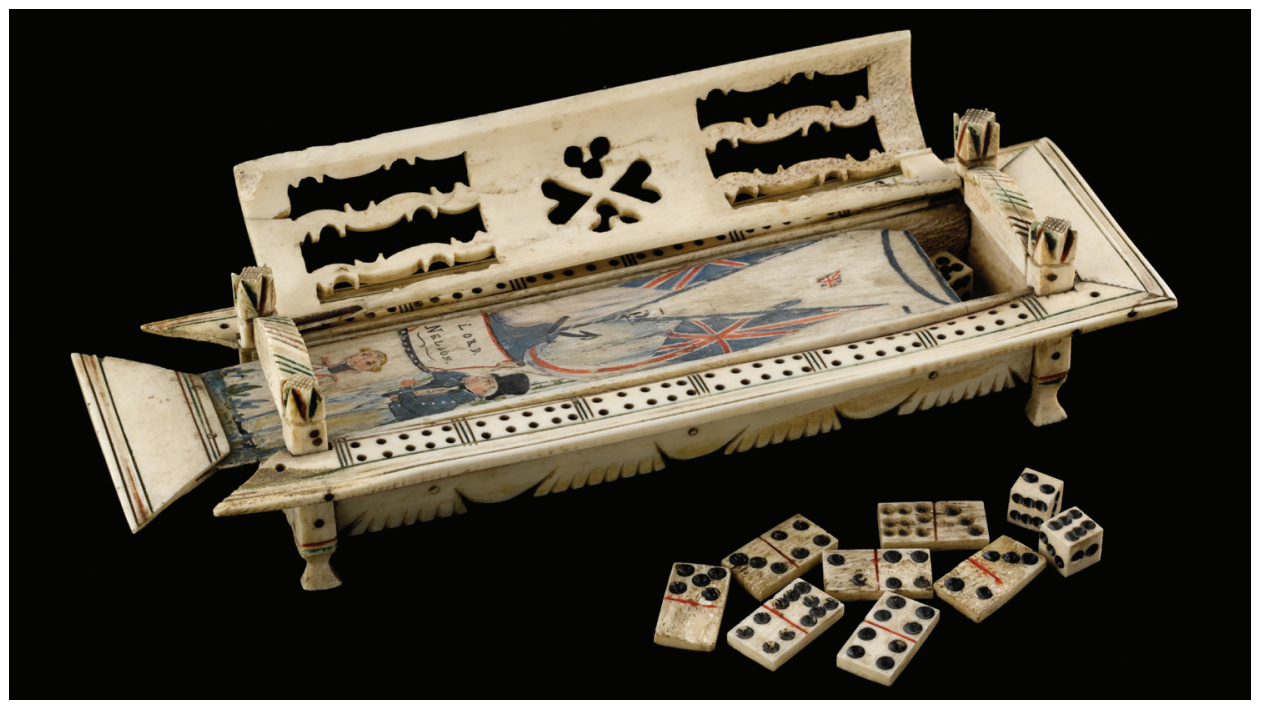

28 Though life on board the hulks was oppressive, imprisoned sailors found ways to pass the time and even earn money. This cribbage board, carved from bone by a French prisoner, was probably sold to one of his British captors. A pull-out slide beneath the lid shows a sailor mourning beside a monument with a profile inscribed 'LORD NELSON'.

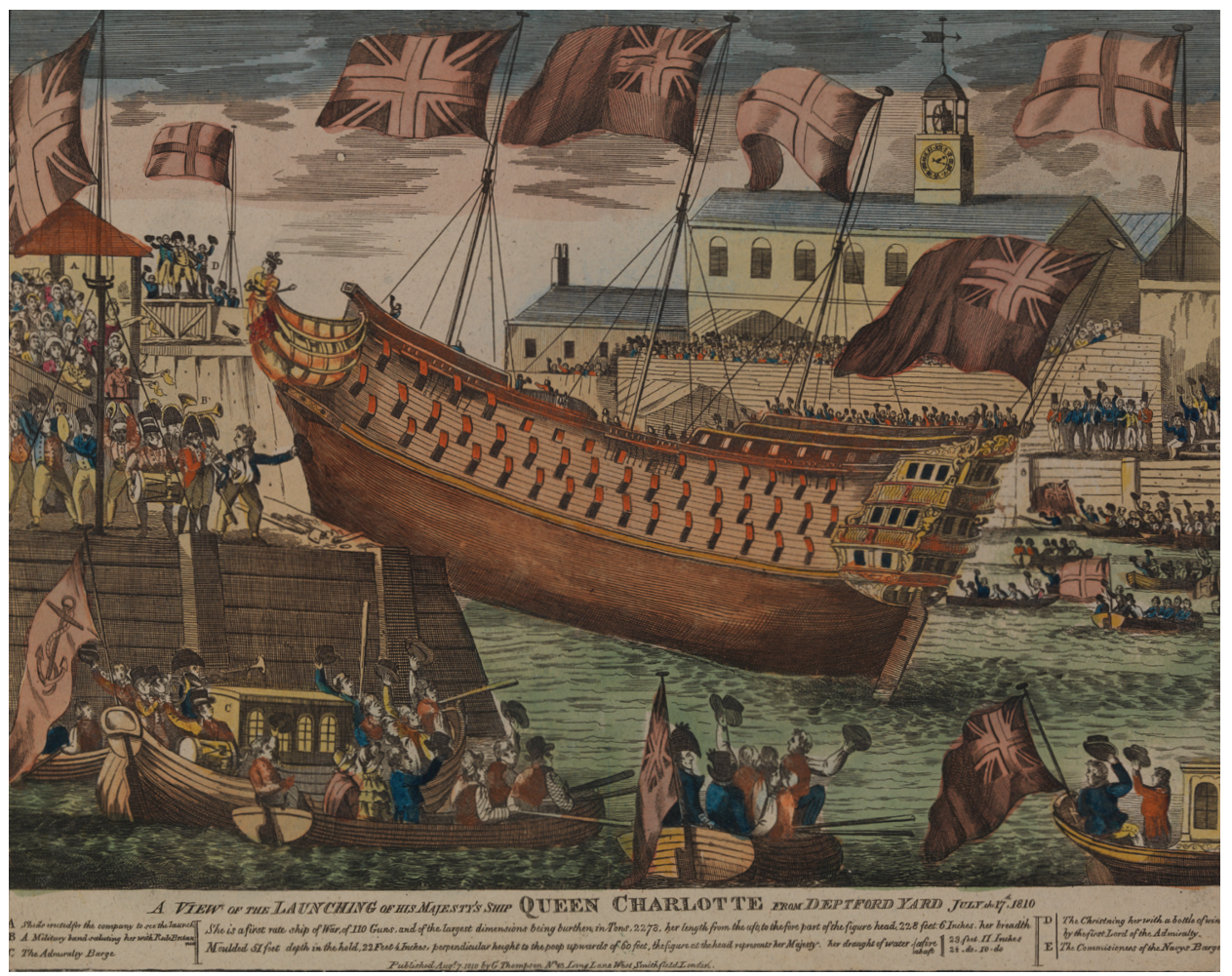

29 Ship launches were incredible spectacles that brought the British public face to face with the Royal Navy. They were deliberately patriotic events: anthems were sung, the Union Jack was flown, and every attempt was made to encourage pomp and ceremony. This print depicts the launching of the first rate ship Queen Charlotte in 1810, which was attended by tens of thousands of people. 


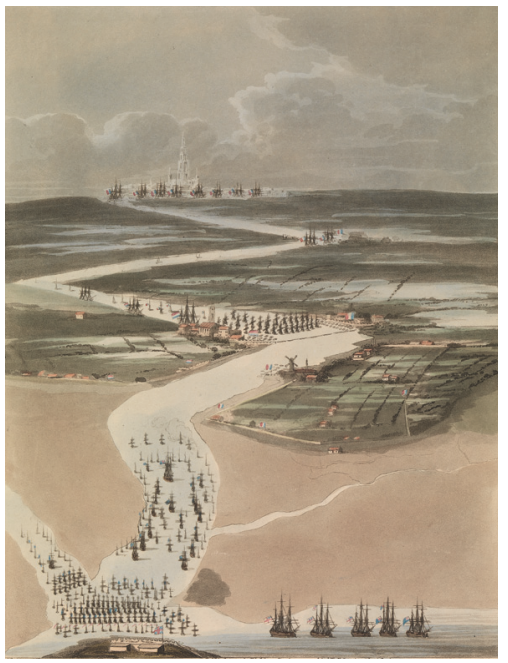

30 The British expedition to Walcheren in 1809 was a disaster for both the navy and the army. Progress up the river Scheldt was extremely slow, which gave the French time to reinforce the city of Antwerp. With an attack on the city impossible, thousands of British servicemen were struck down by fever. This print shows the difficulty of the approach to Antwerp, as naval forces contended with fortresses, enemy shipping and arduous navigation.

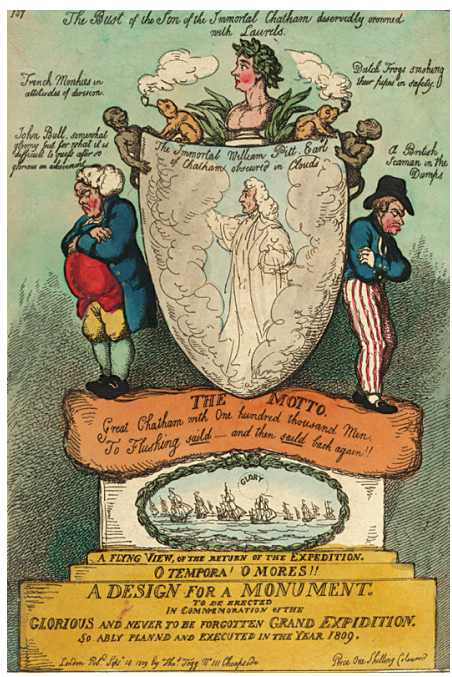

31 The failure of the Walcheren expedition caused a public outcry in Britain. This caricature takes the ironic form of a monument designed to celebrate the 'glorious and never to be forgotten Grand Expedition'. The expedition's general, Earl Chatham, was criticised for his dawdling, but the navy, which had performed valiantly, avoided the worst of the criticism. Here a British sailor is shown down 'in the dumps', dismayed by the incompetence of his military peers.

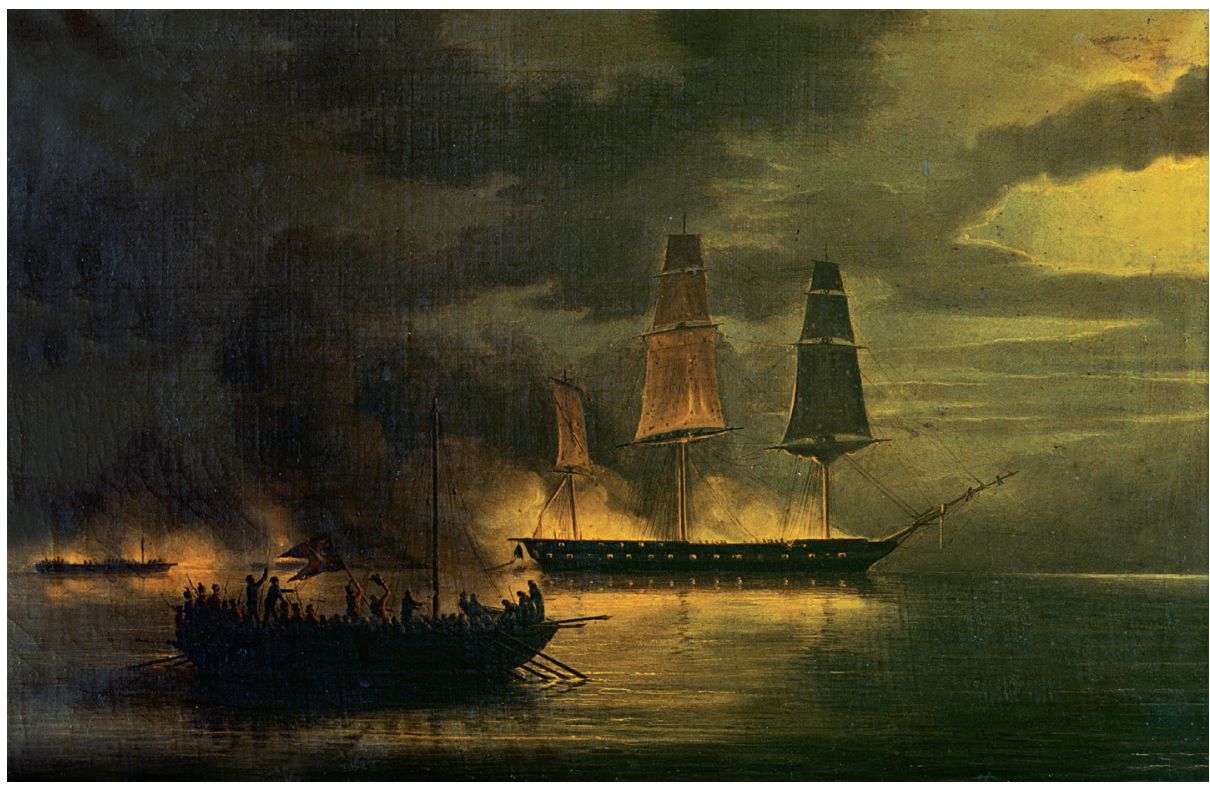

32 The conflict in northern Europe pitted the warships of the Royal Navy against the smaller gunboats of the Danish navy, which were ideally suited to the shallow waters at the entrance to the Baltic. In 1809 the British frigate Melpomene was attacked by a flotilla of these vessels and suffered considerable damage to her hull, sails and rigging. Though it eventually escaped, countless other ships entering and leaving the Baltic were less fortunate. 


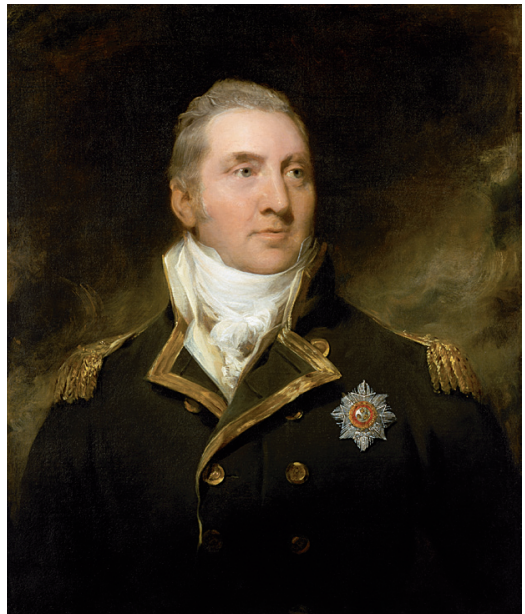

33 Tough and uncompromising, Edward Pellew effortlessly made the transition from audacious frigate captain to accomplished fleet commander. His deft handling of the East Indies Fleet under trying circumstances was a remarkable achievement, and while he did not always see eye to eye with the Admiralty, his command of the Mediterranean fleet from 1811 was exemplary. By the end of the war he was Britain's leading admiral, and in 1816 led a successful British naval expedition to Algiers.

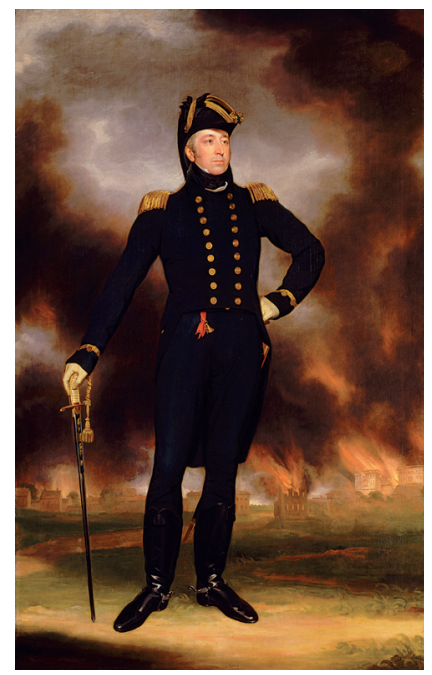

35 A zealous and ruthless commander, George Cockburn had no qualms about waging 'total war' along the east coast of the United States, attacking both military and civilian targets. This portrait shows him standing before the burning American capital, striking a typically nonchalant pose. That he later chose to be depicted against this controversial background shows Cockburn's undiminished pride in his achievements.

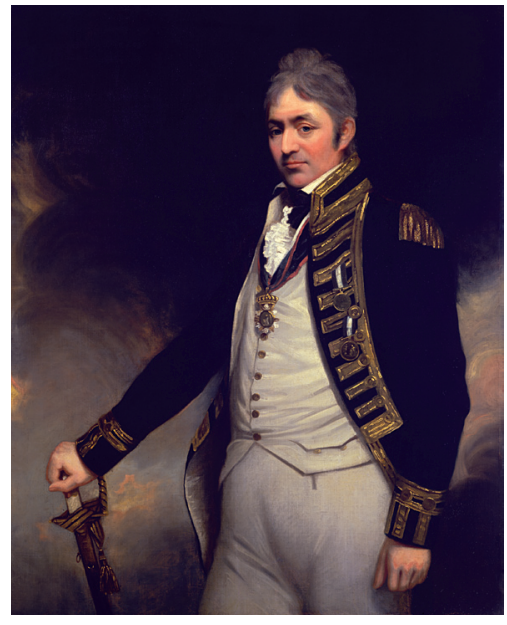

34 Feted early in his career as the most promising officer of his generation, Thomas Troubridge never realised his full potential. Though an excellent seaman, his close association with St Vincent won him few friends, and he proved incapable of navigating the difficult politics of the East Indies station. Desperate to take up command at the Cape of Good Hope, this proud and headstrong officer put to sea in hurricane season and was lost with his entire crew in a tropical storm.

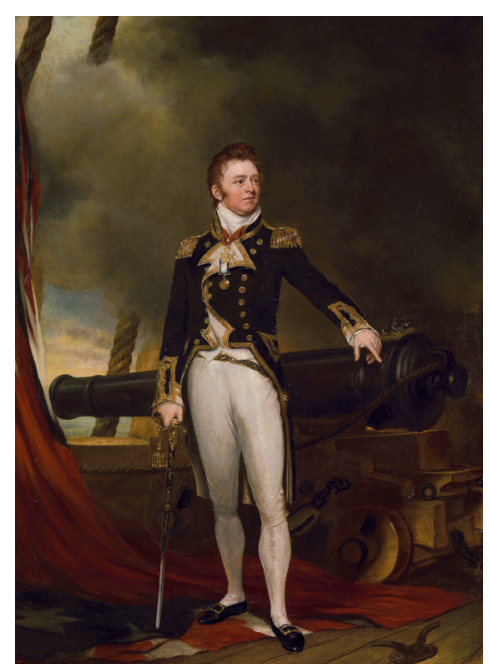

36 Best known for the Shannon-Chesapeake action of 1813, Philip Bowes Broke's victory restored the Royal Navy's reputation after a series of frigate losses during the War of 1812. It came at a high personal cost: he was seriously wounded by a cutlass blow to the head. The injury caused him chronic health problems which ended his naval career. These were later aggravated by a fall from his horse and he died in 1841. 


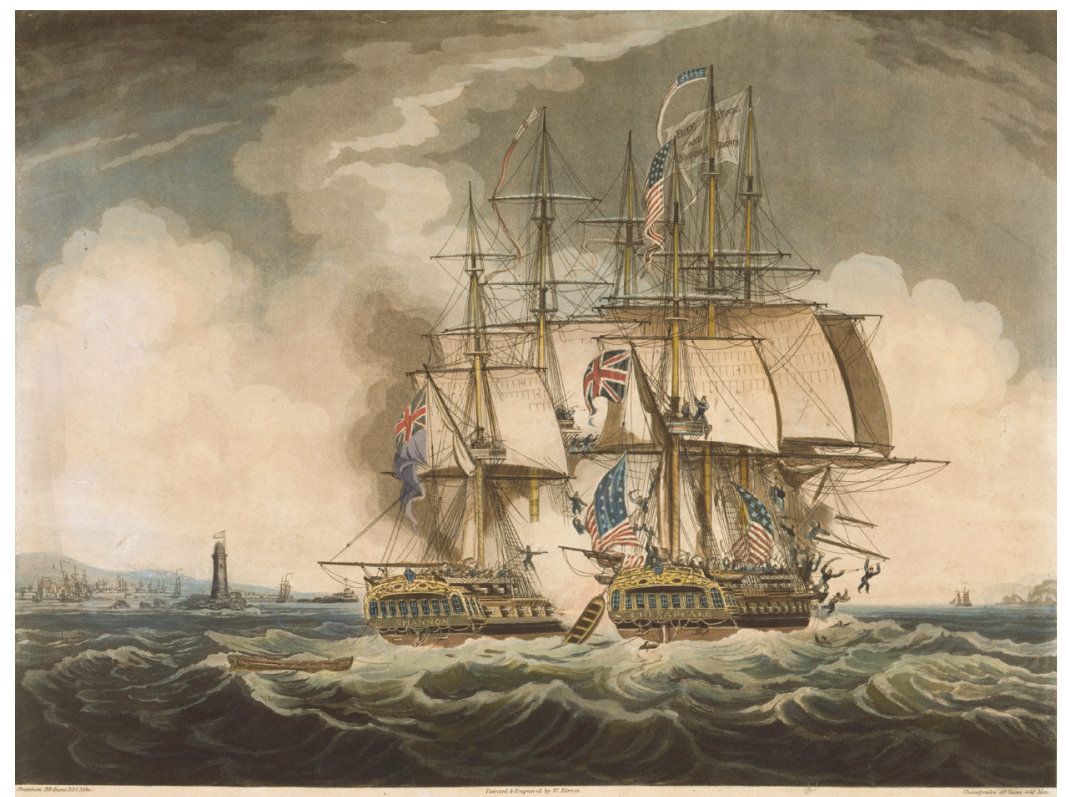

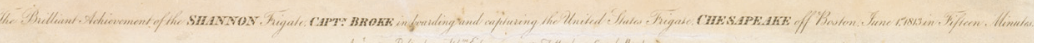

37 Philip Bowes Broke's capture of the American frigate Chesapeake was celebrated across Britain, with countless depictions produced and sold in the print shops of London. In the latter years of the war the army received considerable public attention, and actions like this were an important reminder that Britain's interests and security continued to rely on the Royal Navy.

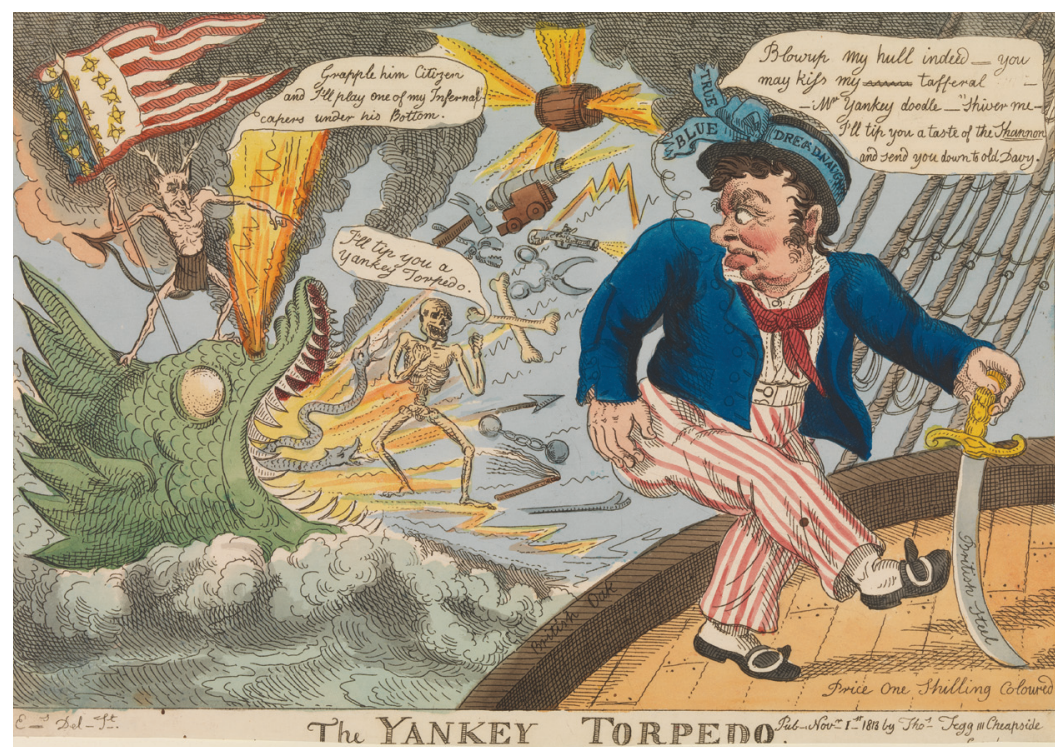

38 Early in the Napoleonic Wars, the American engineer Robert Fulton was employed by the British to develop his torpedo technology, though it proved largely ineffective. Fulton took the weapon to the United States, and a decade later it was used against the British during the defence of New York. Seemingly oblivious to Britain's earlier dalliance with the new invention, this caricaturist was indignant at the use of a weapon that appeared to contravene the accepted rules of war. 


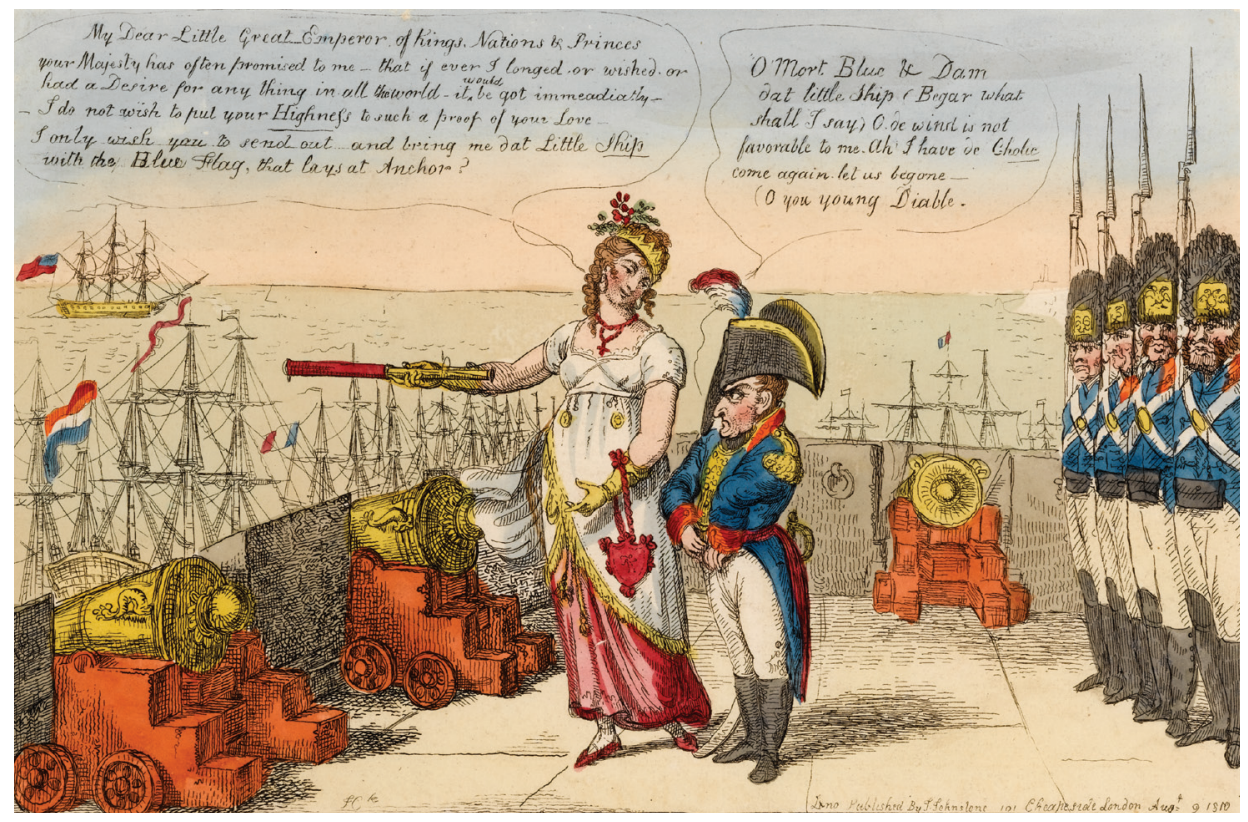

39 By 1810 the Royal Navy had secured an unprecedented command of the world's oceans. This caricature plays on Napoleon's impotence at sea, depicting a small British ship blockading a vast French fleet. The image was comforting to the British public, but in reality Napoleon's navy was far from a spent force. French fleets escaped from port with alarming regularity right until the end of the war and remained a constant menace to the watching Royal Navy.

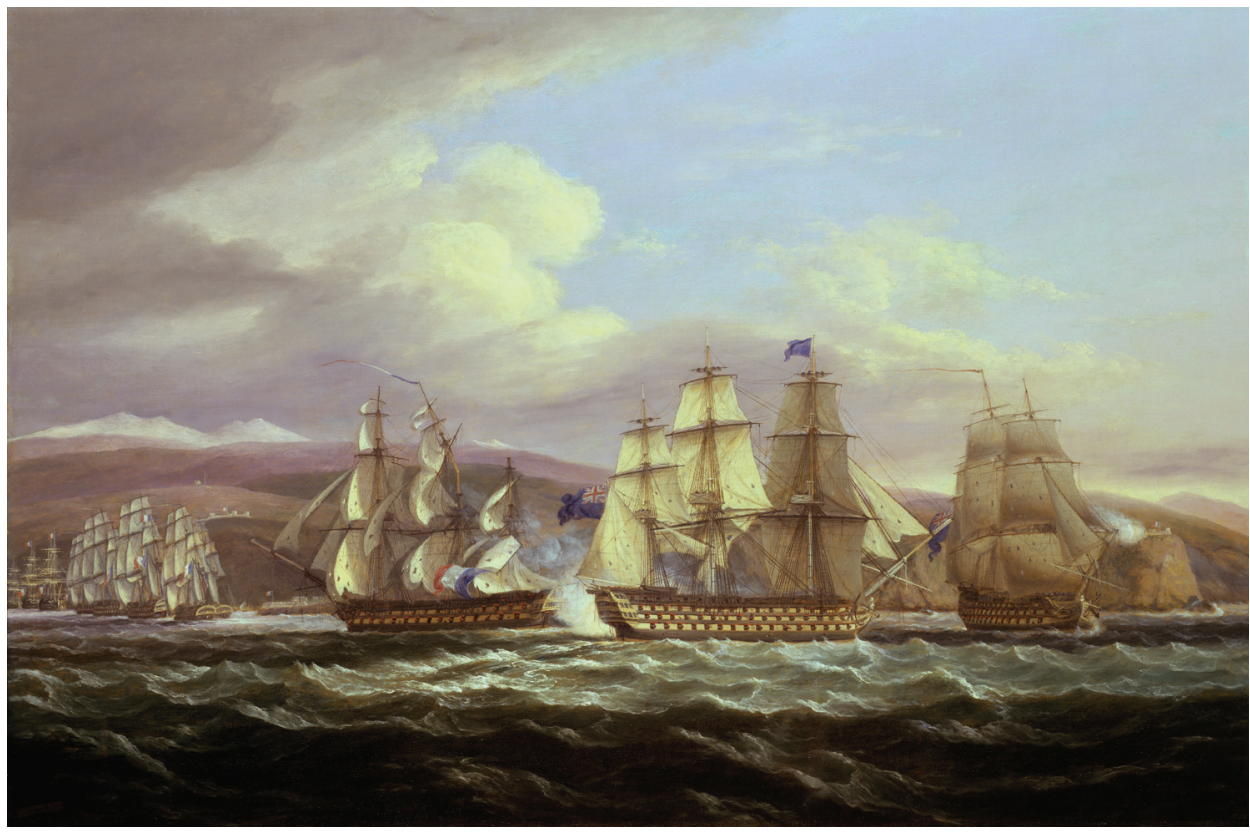

40 By the end of 1813 the French fleet at Toulon numbered twenty-one ships of the line, larger than the blockading British force. On 5 November it put to sea, where it met the Mediterranean fleet commanded by Vice-Admiral Sir Edward Pellew. The advanced British ships exchanged fire with the French and forced them back into port, a moment captured in this arresting painting. 


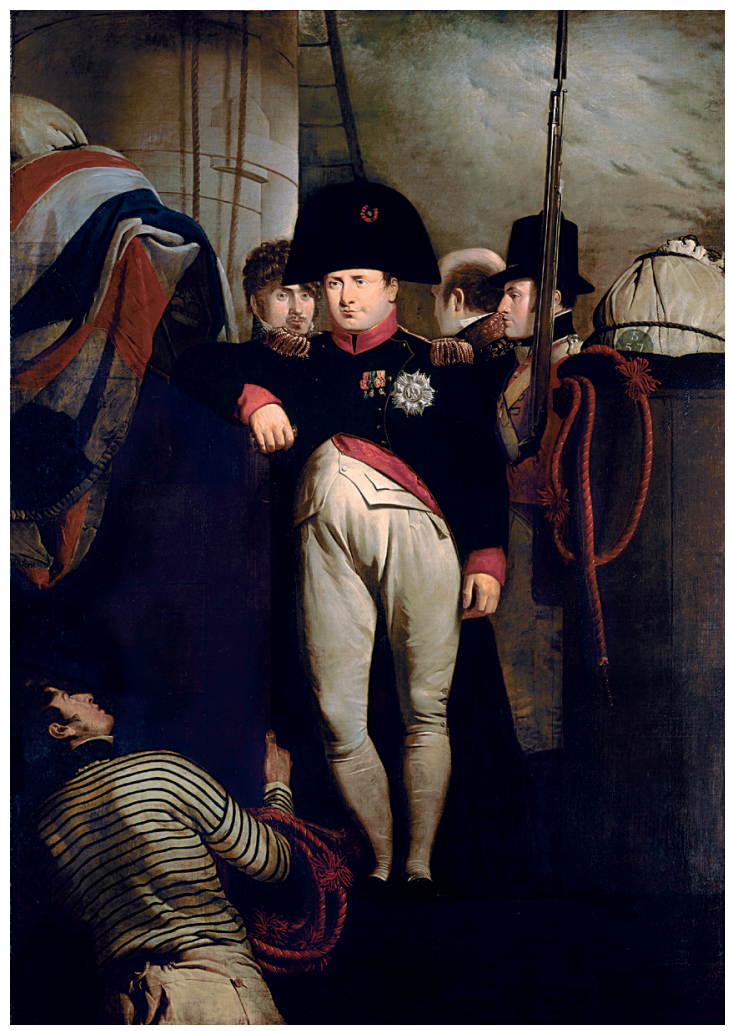

41 Napoleon's surrender to Captain Maitland of HMS Bellerophon signalled the end of the Napoleonic Wars. Here the former French emperor is depicted with members of his entourage as a prisoner on board the British warship. While Napoleon dominates the scene, the symbolic positioning of the Union Jack and the British sailor leaves the viewer in no doubt that the navy had caged the 'Corsican Ogre'.

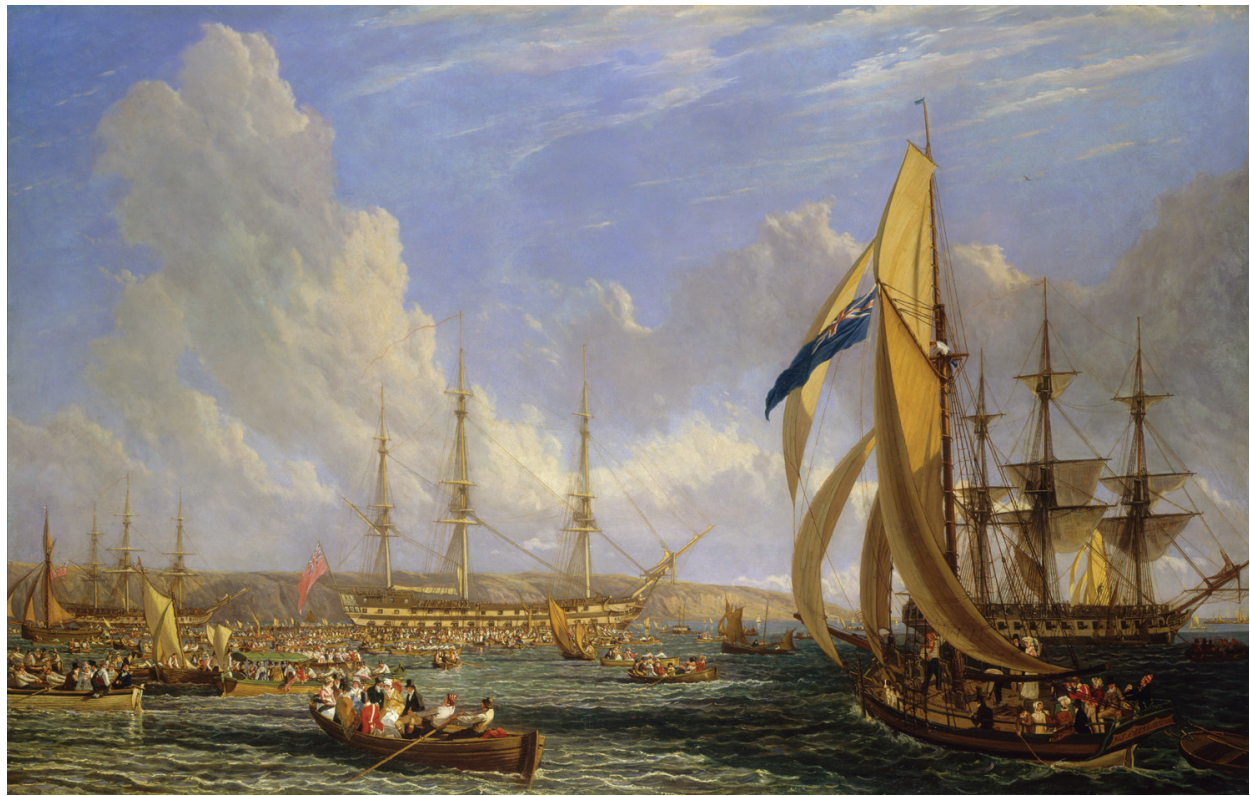

42 Following Napoleon's surrender, thousands of curious spectators came to catch a glimpse of the man who had conquered and lost a European empire. As this painting demonstrates, the crowds were keen to get as close as possible, much to the annoyance of naval commanders. Napoleon's regular appearances on deck did little to discourage public fascination. 